\title{
Effect of Lactobacillus plantarum with antioxidant properties on the flavour and oxidation of Chinese sausages
}

\author{
Lin Mei ${ }^{1,2^{*}}$, Dongmei Pan ${ }^{1}$,Tingting Guo ${ }^{1}$, Yulu Wang ${ }^{1}$, Qiuya Ji ${ }^{1}$ and Li Wang ${ }^{1 *}$ \\ 1 Anhui Engineering Laboratory of Agro-products Processing, College of Tea and Food Science, Anhui \\ Agricultural University, 130 Changjiang West Road, Hefei, 230036, Anhui, P.R. China \\ 2 State Key Laboratory of Tea Plant Biology and Utilization, Anhui Agricultural University,130 Changiiang \\ West Road, Hefei, 230036, Anhui, P.R. China \\ meilinl@ahau.edul.cn(L.M.); pptx688@126.com(DM.P.); gtt18856718355@163.com(TT.G.) \\ xiaowang961109@sina.com(YL.W.); jqy19970825@icloud.com (QY.J.) \\ * Correspondence: meilin@ahau.edu.cn and Lwan@ahau.edu.cn
}

\begin{abstract}
Effects of Lactobacillus plantarum (L. plantarum) strain P3 and mutant strain P3-M2 with antioxidant properties on fermented sausage flavour via lipid and protein oxidation inhibition were investigated. The commerical strain was used to as positive control (control group). Results showed that P3 and P3-M2 had the ability of reducing lipid and protein oxidantion during fermentation. The increase of lipoxygenase activity and thiobarbituric acid reactive substances (TBARS) values were retarded. Metmyoglobin (MetMb) content relatively decreased significantly $(p<0.05)$, while sulfhydryl group contents were significantly higher than those in the control $((p<0.05)$. Futhermore, changes in protein bands were confrimed with the less protein oxidation with P3-M2 than P3 and the control. Additionally, strain P3 and P3-M2 significantly enhanced the type and relative content of esters after fermented $(p<0.05)$, indicating that strain P3 and P3-M2 contributed to the production of flavor substances. These results revealed that $L$. plantarum strains with antioxidant properties were a promising approach in inhibiting lipid and protein oxidation of chinese sausage, maintaining the stable natural structure of protein, simultaneously improve the quality of sausage and promote the sausage to form a better flavor.
\end{abstract}

Keywords: Lactobacillus plantarum; Chinese sausage; antioxidation; flavour; quality

\section{Introduction}

Chinese fermented sausage is a popular traditional meat product widely preferred by consumers because of its characteristic flavour [1]. Lactic acid bacteria (LAB) and their fermentation products are generally recognised as safe, guaranteeing that have been widly utilised in food [2]. In recent years, an increasing number of researchers have focused on $L A B$ fermentation to improve flavour and ensure food safety.

Many effect of LAB on flavour substances have been reported. The higher amount of volatile compounds and organic acids due to the adjunct Lactobacillus paracasei 4341 led to a clear differentiation of the experimental Caciotta compared to the control in terms of aromatic profile, colour, texture, and sensory perception [3]. A co-culture of L. harbinensis M1 and L. casei M8 produced a fermented soymilk product with both markedly improved flavour and good probiotic potential [4]. Lactobacillus, the dominant bacteria in fermented rice noodles, grow rapidly to inhibit the growth of undesirable bacteria and produce various low-threshold volatile compounds, including aldehydes, esters, alcohols, and ketones. A significant correlation between bacterial communities and major volatile compounds in dry sausages was found, and the core bacteria, including Lactococcus lactis, L. plantarum, L. alimentarius, and L. sakei and Weissella hellenica, contributed to the development of the major volatile compounds [5]. Thus, LAB 
fermentation contributes to the production of complex flavour components, such as amino acids, vitamins, and organic acids, which improve the flavour, taste, and other properties of fermentation broth [6].

Oxidation is one of the main causes of deterioration of Chinese fermentation sausages and may cause taste, texture, discolouration and other undesirable effects, such as loss of essential fatty acids and amino acids [7,8]. Therefore, the lipid and protein oxidation during the manufacturing and storage of meat products, is still a major research topic in food technology $[9,10]$. Both protein oxidation and lipid oxidation are related to the formation of sausage quality, which is the most remarkable characteristic and important index for quality evaluation [11]. Lipid oxidation greatly affects the quality of meat products and is the main factor limiting the shelf life and flavour of products. During lipid oxidation, secondary oxidation products such as aldehydes, ketones, and acids are produced. These products can contribute to the formation of the unique flavour of sausage but result in an unpleasant smell, even producing malondialdehyde (MDA) and other harmful substances when excessive oxidation occurs [12]. Protein oxidation can occur during sausage fermentation and maturation, potentially changing the structural and functional properties of the proteins [13]. This also has important effect on the quality, nutritional value, and sensory characteristics of fermented sausages [14].

However, effects of the application of L. plantarum with antioxidant properties as a starter culture to mediate the flavour and oxidtion of sausage during fermentation remain unclear. Therefore, this study aimed to investigate the effects of L. plantarum as a fermentation strain on the flavour of sausages by regulating protein and lipid oxidation during fermentation and ripening.

\section{Materials and Methods}

\subsection{Materials and chemicals}

Pork fat and lean pork were purchased from Hongfu Supermarket (Hefei, Anhui Province, China). Before each trial of sausage preparation, pork meat was trimmed to remove visible connective tissues and fat. The sausages were prepared using $70 \%$ pork meat and $30 \%$ pork fat in a total mass of $50 \mathrm{~kg}$. After the pork meat and pork fat were minced, the ingredients including salt $(3 \%, w / w)$, sugar $(7 \%, w / w)$, sodium glutamate $(0.2 \%, w / w)$, five flavoured powder $(0.1 \%, w / w)$, ginger powder $(0.15 \%, w / w)$, and Daqu liquor $(2 \%, v / w)$ were added. The five flavoured powder and ginger powder were purchased from Hongfu Supermarket (Hefei, Anhui Province, China). The mixture was divided into three groups. The first group was set as the control group by adding 200 $\mathrm{mg} / \mathrm{kg}$ of the commercial strain Lactobacillus Speed 1.0. The second group was added with $200 \mathrm{mg} / \mathrm{kg}$ of L. plantarum strain P3 (P3 group). The third group was added with 200 $\mathrm{mg} / \mathrm{kg}$ of mutant strain P3-M2 (P3-M2 group).

The mixtures were stuffed in natural casings with a $4-\mathrm{cm}$ diameter and $10-\mathrm{cm}$ length. All treatments were performed in three different batches for experimental replication, and sausages were placed in a fermentation room and ripened for three periods. In the first stage of fermentation, the relative humidity $(\mathrm{RH})$ and temperature were set at $95 \%$ and $30 \pm 0.5^{\circ} \mathrm{C}$, respectively, for 1 day. Then, the temperature was adjusted to $16 \pm 0.5^{\circ} \mathrm{C}$, and $\mathrm{RH}$ was successively decreased to $90 \%, 87 \%$, and $85 \%$, and the duration of each $\mathrm{RH}$ was 2 days. The fermentation temperature of the third stage was $12 \pm 0.5^{\circ} \mathrm{C}$, and the $\mathrm{RH}$ was set at $85 \%, 80 \%$, and $75 \%$, and each $\mathrm{RH}$ condition lasted 7 days. The total ripening period was 28 days. Samples were taken from each group at 4, 10, 16, 22, and $28 \mathrm{~d}$ of fermentation. DPPH was purchased from Beijing Zhongsheng Ruitai Technology Co., Ltd., O-phenanthroline was purchased from Tianjin Fu Technology Development Co., Ltd., $\mathrm{K}_{2} \mathrm{HPO}_{4}, \mathrm{KH}_{2} \mathrm{PO}_{4}, \mathrm{NaH}_{2} \mathrm{PO}_{4}, \mathrm{NaCl}$, and $\mathrm{H}_{2} \mathrm{O}_{2}$ were obtained from Xilong Chemical Co., Ltd., pyrogallol, potassium ferricyanide, trichloroacetic acid were obtained from Shanghai McLean Biological Reagent Co., Ltd., and the T-AOC kit, carbonyl 
determination kit, and sulfhydryl determination kit were obtained from Nanjing Jiancheng Bioengineering Research Institute (Nanjing, Jiangsu Province, China).

\subsection{Bacterial cultures and culture media}

One L. plantarum strain P3 was previously isolated from Chinese sausages and identified by $16 \mathrm{~S}$ rDNA sequencing was used in this study. P3-M2 was a mutant strain of P3 and was identified by 16S rDNA sequencing. De Man, Rogosa, Sharpe (MRS) agar and MRS broth used to culture strain were obtained from Hangzhou Best Bio Technology Co., Ltd.

\subsection{Determination of free radical scavenging ability}

\subsubsection{Hydroxyl radical-scavenging assay}

The hydroxyl radical $(\mathrm{OH})$-scavenging assay was performed according to the method described by Noureen et al.[15] with some modifications. The reaction mixture contained $1.0 \mathrm{~mL}$ of ethanolic salicylic acid solution $(5 \mathrm{mM}), 1.0 \mathrm{~mL}$ of $\mathrm{FeSO}_{4}(2.5 \mathrm{mM})$ and $1.0 \mathrm{~mL}$ of $\mathrm{H}_{2} \mathrm{O}_{2}(20 \mathrm{mM})$. The solution was mixed with $1.0 \mathrm{~mL}$ of the sample, and then deionised water was added to a volume of $10 \mathrm{~mL}$. The mixture was incubated at $37^{\circ} \mathrm{C}$ for $90 \mathrm{~min}$, and the absorbance of the resulting solution was measured at $536 \mathrm{~nm}$ after centrifugation at $6000 \times g$ for $10 \mathrm{~min}$. The control group contained an equal volume of deionised water instead of the sample. The $\mathrm{OH}$-scavenging activity was expressed as follows:

Scavenging activity $(\%)=\left[1-\left(\mathrm{A}_{\text {sample }}-\mathrm{A}_{\text {blank }}\right) / \mathrm{A}_{\text {control }}\right] \times 100$.

\subsubsection{DPPH radical-scavenging assay}

The DPPH free radical-scavenging capacity of L. plantarum was evaluated according to the method described by Pil-Nam et al. [16] with some modifications. Briefly, $2.0 \mathrm{~mL}$ of the sample was added to the same volume of an ethanolic DPPH radical solution (0.4 $\mathrm{mM}$ ). The reaction solution was mixed vigorously and incubated at room temperature in the dark for $30 \mathrm{~min}$. The control group contained an equal volume of deionised water instead of the sample. The blank group contained an equal volume of ethanol instead of $\mathrm{DPPH}$ radical solution. The absorbance of the solution was measured at $517 \mathrm{~nm}$ after centrifugation at $8000 \times \mathrm{g}$ for $10 \mathrm{~min}$. The scavenging ability was defined as follows:

Scavenging activity $(\%)=\left[1-(\right.$ A sample - Ablank $\left.) / A_{\text {control }}\right] \times 100$.

\subsubsection{Ferrous ion-chelating ability}

The $\mathrm{Fe}^{2+}$-chelating ability was estimated using the method described by Lin and Yen [17]. First, $0.5 \mathrm{~mL}$ of the sample was mixed with $0.1 \mathrm{~mL}$ of ascorbic acid $(10 \mathrm{~g} / \mathrm{L}), 0.1 \mathrm{~mL}$ of $\mathrm{FeSO}_{4}(4 \mathrm{~g} / \mathrm{L})$, and $1 \mathrm{~mL}$ of $\mathrm{NaOH}(0.2 \mathrm{M})$. The mixture was incubated at $37^{\circ} \mathrm{C}$ in a water bath for $20 \mathrm{~min}$, and $0.2 \mathrm{~mL}$ of TCA (10\%) was added. The supernatant was obtained by centrifugation at $4500 \times \mathrm{g}$ for $10 \mathrm{~min}$, and $1.5 \mathrm{~mL}$ of 1,10 -phenanthroline $(1 \mathrm{~g} / \mathrm{L})$ was added. After allowing the reaction to proceed for $10 \mathrm{~min}$, the absorbance was measured at $510 \mathrm{~nm}$.

\subsubsection{Superoxide anion -scavenging assay}

The superoxide anion radical scavenging assay was performed using an improved pyrogallol autoxidation method [18]. First, $0.1 \mathrm{~mL}$ of the sample was added to $4.5 \mathrm{~mL}$ of Tris- $\mathrm{HCl}$ solution $(0.05 \mathrm{M}, \mathrm{pH} 7.0)$. The reaction mixture was incubated at $25^{\circ} \mathrm{C}$ for 20 min. Subsequently, $0.4 \mathrm{~mL}$ of pyrogallol $(2.5 \mathrm{mM})$ was added, and the mixture was incubated at room temperature for $4 \mathrm{~min}$. Then, two drops of $\mathrm{HCl}(8 \mathrm{M})$ were added to stop the reaction, and the absorbance was measured at $306 \mathrm{~nm}$. The control group 
contained an equal volume of deionised water instead of the sample. The $\mathrm{O}_{2}$-scavenging activity is expressed as:

Scavenging activity $(\%)=[1-($ Asample - Ablank $) /$ Acontrol $] \times 100$.

\subsection{Preparation of the fermented sausage}

Sausages were prepared according to the method described by Ge et al.[14] with some modifications. A total of $70 \%$ pork meat and $30 \%$ pork fat was minced, and the ingredients including salt $(3 \%, w / w)$, sugar $(7 \%, w / w)$, sodium glutamate $(0.2 \%, w / w)$, five flavoured powder $(0.1 \%, w / w)$, ginger powder $(0.15 \%, w / w)$, and Daqu liquor $(2 \%$, $\mathrm{v} / \mathrm{w}$ ) were added. The mixture was divided into three groups. One group was set as the control with a commercial fermentation strain (strain Lactobacillus Speed 1.0). The other groups were supplemented with Lactobacillus plantarum (L. plantarum) P3 (P3 group) and L. plantarum P3-M2 (P3-M2 group).

\subsection{Lipid oxidation}

\subsubsection{Determination of TBARs value of sausage}

Among the various parameters used to reflect lipid oxidation, the most common is determining the TBAR value [19]. Lipid oxidation was assessed by the thiobarbituric acid reactive substances (TBARS) procedure [20] with some modifications. Chopped sausage $(5 \mathrm{~g})$ was blended with $50 \mathrm{~mL}$ of trichloroacetic acid mixed solution, sealed, and oscillated at $50^{\circ} \mathrm{C}$ for $30 \mathrm{~min}$. The mixture was filtered using a double Whatman filter paper. Then, $5 \mathrm{~mL}$ of filtrate and $5 \mathrm{~mL}$ of $20 \mathrm{mM}$ TBA were transferred into a tube, covered, and heated at $90^{\circ} \mathrm{C}$ for $30 \mathrm{~min}$. The concentration of malondialdehyde (MDA, $\mathrm{mg} / \mathrm{kg}$ sausage) was measured by determining the absorbance of the solution using a UV spectrophotometer at $532 \mathrm{~nm}$ of wavelength.

\subsubsection{Determination of peroxide value of sausage}

The lipid extraction method described by Ying et al. [21] was used. POV measurement was performed using the Chinese National Standard (GB/T 5538-2005). The lipid extract $(5.0 \mathrm{~g})$ was completely dissolved in $50 \mathrm{~mL}$ of component solvent (acetic acid: isooctane $=3: 2, \mathrm{v} / \mathrm{v})$, and saturated potassium iodide solution $(0.5 \mathrm{~mL})$ was added and placed in the dark for $3 \mathrm{~min}$. Then, $30 \mathrm{~mL}$ of distilled water was added and titrated with $0.01 \mathrm{~mol} / \mathrm{L}$ sodium thiosulfate solution to the mixture until the blue colour disappeared. A $0.5 \mathrm{~mL}$ of starch solution $(1 \%, \mathrm{~m} / \mathrm{v})$ was used as an indicator.

\subsection{Protein oxidation}

\subsubsection{Protein preparation}

Sarcoplasmic and myofibrillar protein extracts were prepared from sausages according to the method described by Di Yu et al. [22] with some modifications. A $10 \mathrm{~g}$ of chopped sausage was homogenized with a $100 \mathrm{~mL} 0.03 \mathrm{M}$, pH $6.5 \mathrm{Na}_{2} \mathrm{HPO}_{4}-\mathrm{NaH}_{2} \mathrm{PO}_{4}$ buffer by high-speed homogeniser (IKA, Staufen, Germany) for $3 \mathrm{~min}$, centrifuged at $8000 \mathrm{rpm} / \mathrm{min}$ for $20 \mathrm{~min}$ at $4^{\circ} \mathrm{C}$. The supernatant was dialysed in distilled water to obtain sarcoplasmic protein. The precipitate was homogenised with a $0.03 \mathrm{M}, \mathrm{pH} 6.5$ $\mathrm{Na}_{2} \mathrm{HPO}_{4}-\mathrm{NaH}_{2} \mathrm{PO}_{4}$ buffer at a mass-to-volume ratio of $1: 10(\mathrm{~W} / \mathrm{V})$ for $3 \mathrm{~min}$, centrifuged at $8000 \mathrm{rpm}$ for $20 \mathrm{~min}$ at $4^{\circ} \mathrm{C}$, and was repeated twice. The precipitate was homogenised with a $0.1 \mathrm{M}$, pH $6.5 \mathrm{Na}_{2} \mathrm{HPO}_{4}-\mathrm{NaH}_{2} \mathrm{PO}_{4}$ buffer containing $0.7 \mathrm{M} \mathrm{KI}$ and $0.02 \% \mathrm{NaN}_{3}$ at a mass-to-volume ratio of 1: $4(\mathrm{~W} / \mathrm{V})$, centrifuged at $10000 \mathrm{rpm}$ for $20 \mathrm{~min}$ at $4^{\circ} \mathrm{C}$. The supernatant was dialysed in distilled water to obtain myofibrillar protein. The concentration of the obtained protein was determined using a TP kit. 


\subsubsection{Carbonyl content}

The carbonyl group was determined according to a previously reported method with slight modifications [23]. MPs were diluted to a $5 \mathrm{mg} / \mathrm{mL}$ with $15 \mathrm{mM}$ PIPES buffer (15 mM PIPES, $600 \mathrm{mM} \mathrm{NaCl}, \mathrm{pH}$ 6.0). Two groups of $0.8 \mathrm{~mL} \mathrm{MP}$ solutions were obtained. One was treated with $1.6 \mathrm{~mL}$ of $3 \mathrm{mM} \mathrm{HCl}$ containing $0.3 \%(\mathrm{w} / \mathrm{v}) 2$, 4-dini-trophenylhydrazine, and the other was treated with $1.6 \mathrm{~mL}$ of $3000 \mathrm{mM} \mathrm{HCl}$. After the solutions were reacted for $30 \mathrm{~min}$ at room temperature, $0.8 \mathrm{~mL}$ of trichloroacetic acid $(40 \%, \mathrm{w} / \mathrm{v})$ was added to each solution and centrifuged $\left(2500 \times \mathrm{g}, 5 \mathrm{~min}, 4{ }^{\circ} \mathrm{C}\right)$. The supernatant was removed. Next, $2 \mathrm{~mL}$ of the mixture (ethanol: ethyl acetate $=1: 1$ ) was mixed with the precipitate, centrifuged under the same conditions, and washed three times. The precipitate was dissolved by adding $3 \mathrm{~mL}$ of $20 \mathrm{mM}$ polarisation beam splitter (PBS) ( $\mathrm{pH}$ 6.5) containing $600 \mathrm{mM}$ guanidine hydrochloride. The absorbance was measured at $370 \mathrm{~nm}$, and the protein carbonyl content was determined using the molar extinction coefficient $\left(22,000 \mathrm{M}^{-1} \mathrm{~cm}^{-1}\right)$ as follows:

$$
\text { Carbonyl content }(\mathrm{nmol} / \mathrm{mg})=\frac{3 \times A \times 10^{6}}{\operatorname{C\times v} \times 22500} \text {. }
$$

\subsubsection{Sulfhydryl content}

The total sulfhydryl content was determined according to previously described methods [24]. MPS was diluted to $10 \mathrm{mg} / \mathrm{mL}$ with $15 \mathrm{mM}$ PIPES buffer (15 mM PIPES, $600 \mathrm{mM} \mathrm{NaCl}, \mathrm{pH} 6.0$ ). Then, $3 \mathrm{~mL}$ of the diluted solution was mixed with $0.4 \mathrm{~mL}$ of $0.1 \%$ 2-nitrobenzoic acid, left at $40^{\circ} \mathrm{C}$ for $25 \mathrm{~min}$ in the dark, and then cooled to room temperature. Absorption was measured at a wavelength of $412 \mathrm{~nm}$. The formula used was as follows:

$$
\text { Sulfhydryl content }(\mathrm{nmol} / \mathrm{mg})=\frac{A \times 10^{5}}{136 \times C}
$$

where $\mathrm{A}$ is the absorbance and $\mathrm{C}$ was the protein concentration.

\subsubsection{MetMb analysis}

MetMb content was determined according to the method described by Samaoui et al. [25]. Chopped sausage ( $5 \mathrm{~g})$ was homogenised with a $25 \mathrm{~mL}$ iced PB buffer $(0.04 \mathrm{M}$, $\mathrm{pH}$ 6.8) for $10 \mathrm{~s}$, placed at $4{ }^{\circ} \mathrm{C}$ for $1 \mathrm{~h}$, centrifuged at $4500 \mathrm{rpm}$ for $30 \mathrm{~min}$, and the supernatant was filtered with a filter paper. The absorbance of the filtrate was measured using a UV spectrophotometer at wavelengths of 525, 545, 565, and $572 \mathrm{~nm}$. The following formula was used:

$$
\mathrm{MetMb} \%=\left[-2.51\left(\mathrm{~A}_{572} / \mathrm{A}_{525}\right)+0.777\left(\mathrm{~A}_{565} / \mathrm{A}_{525}\right)+0.8\left(\mathrm{~A}_{545} / \mathrm{A}_{525}\right)+1.098\right] \times 100 .
$$

\subsubsection{SDS-PAGE}

The degradation of the extracted sarcoplasmic protein was analysed according to the method described by Chen et al. [26]. The protein was diluted to a concentration of approximately $1 \mathrm{mg} / \mathrm{mL}$, and an equal volume of sample loading buffer was mixed with the protein solution and then heated at $100^{\circ} \mathrm{C}$ for $5 \mathrm{~min}$. A $12 \%$ polyacrylamide separating gel was used to detect protein bands. Twenty microliters of the prepared samples were loaded into each well and run at $80 \mathrm{~V}$ for $30 \mathrm{~min}$ and then at $100 \mathrm{~V}$ for 60 min. The gels were stained with a buffer containing $45 \%$ methanol, $10 \%$ glacial acetic acid, and $0.1 \%(\mathrm{~m} / \mathrm{v})$ coomassie brilliant blue for $30 \mathrm{~min}$ and destained with distilled water overnight until emerging the clean background. Protein bands were scanned using a scanner. 


\subsection{Volatile substance analysis}

The sample was processed by the solid-phase microextraction method described by Song Y et al. [27]. Chopped sausage $(5 \mathrm{~g})$ was placed in a $20 \mathrm{~mL}$ headspace bottle and pressed to $1 / 3$ of the bottle, and cyclohexanone was added as the internal standard. The aging extraction head was inserted into the headspace of the sample bottle and adsorbed at $80^{\circ} \mathrm{C}$ for $60 \mathrm{~min}$, after which the adsorbed extraction head was removed, inserted into the gas chromatograph inlet, and analysed at $250^{\circ} \mathrm{C}$ for $10 \mathrm{~min}$, after which the data were collected and collected again after $50 \mathrm{~min}$. Chromatographic conditions were as follows: a TR-5 MS capillary column $(30 \mathrm{~m} \times 0.25 \mathrm{~mm} \times 0.25 \mu \mathrm{m})$, helium was used as the carrier gas, and the flow rate was set at $1 \mathrm{~mL} / \mathrm{min}$. Heating program:the furnace temperature was maintained at $40^{\circ} \mathrm{C}$ for $3 \mathrm{~min}$, and the temperature was raised to $90^{\circ} \mathrm{C}$ at a heating rate of $5{ }^{\circ} \mathrm{C} / \mathrm{min}$ without maintaining; then, the temperature was increased to $230{ }^{\circ} \mathrm{C}$ at a rate of $10{ }^{\circ} \mathrm{C} / \mathrm{min}$ and maintained for $6 \mathrm{~min}$. Mass spectrometry conditions were as follows: ion source temperature, $200{ }^{\circ} \mathrm{C}$; ionisation mode, $\mathrm{EI}^{+}$; electron energy, $70 \mathrm{eV}$; emission current, $120 \mu \mathrm{A}$; scanning mass range was $30-50 \mathrm{~m} / \mathrm{z}$. The relative percentage of each flavour compound was calculated using the peak area normalisation method.

\subsection{Statistical analysis}

All experimental data were analysed using the software SPSS 24.0. Differences between groups were analysed by ANOVA, and multiple comparisons were performed using the Duncan method. Statistical significance was set at $p<0.05$. Test data are expressed as the mean \pm SD. Three batches of sausages (replicates) were prepared, and all measurements were triplicated for each batch of sausages.

\section{Results and Discussion}

\subsection{Antioxidant ability of P3 and P3-M2}

Hydroxyl radicals are highly oxidising and have a strong influence on all cellular components, including lipids, nucleic acids, and proteins. The free radical scavenging abilities of L. plantarum P3 and P3-M2 fermentation supernatants are presented in Figure 1. Mutant strain P3-M2 was obtained by mutation breeding of P3, with significantly improved comprehensive antioxidant capacity $(p<0.05)$.The hydroxyl radicals, DPPH radical scavenging ability, $\mathrm{Fe}^{2+}$ chelating ability, and superoxide anion scavenging ability (Figure $1 \mathrm{a}, \mathrm{b}, \mathrm{c}, \mathrm{d}$ ) of the P3-M2 fermentation supernatant were all significantly improved $(p<0.05)$. The DPPH free radical scavenging ability was as high as $92.74 \%$, the scavenging rate of L. plantarum P3-M2 on hydroxyl radicals was approximately $65 \%$, and the scavenging rate of superoxide anion was approximately $40.74 \%$. In particular, the $\mathrm{Fe}^{2+}$ chelating ability of P3-M2 was higher than that of P3 by approximately $51.01 \%$. The T-AOC value (Figure 1e) of P3-M2 was $30.85 \pm 0.67$. U/mL, which was $33.78 \%$ higher than that of P3 $(p<0.05)$. It was shown that the mutant strain P3-M2 significantly improved the ability to scavenge free radicals and antioxidant capacity. 
(a)

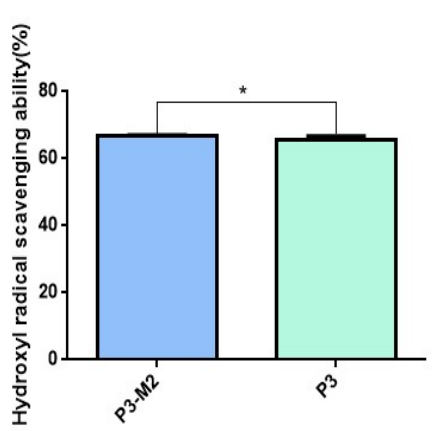

(b)

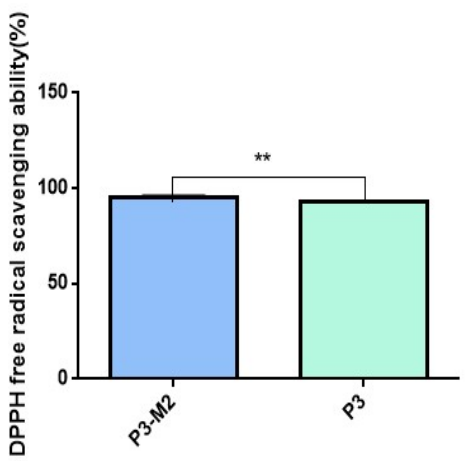

(c)

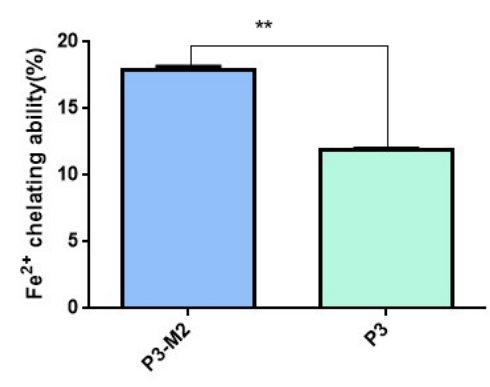

(d)

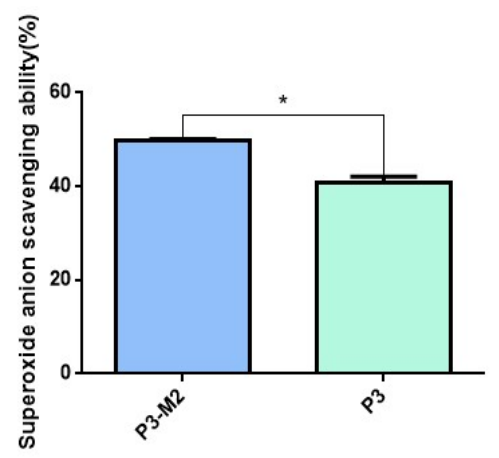

(e)

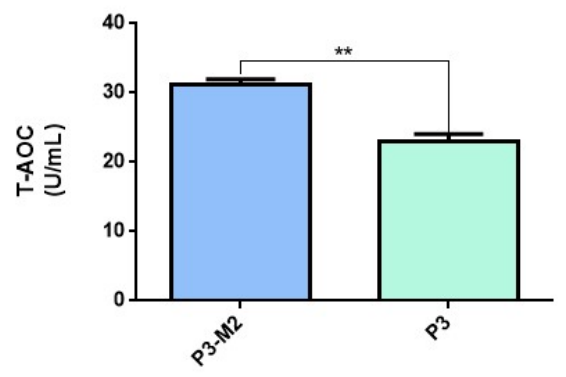

Figure 1. Free radical scavenging ability of fermentation supernatant from Lactobacillus plantarum P3-M2 and P3. (a)The hydroxyl radicals ability of the P3-M2 fermentation supernatant, (b)The DPPH radical scavenging ability of the P3-M2 fermentation supernatant, (c)The $\mathrm{Fe}^{2+}$ chelating ability of the P3-M2 fermentation supernatant, (d)The superoxide anion scavenging ability of the P3-M2 fermentation supernatant, (e)The Total AOC(T-AOC) of the P3-M2 fermentation supernatant. * above the bars indicate statistically significant differences $(p<0.05)$.

\subsection{Lipid oxidation}

\subsubsection{TBARs value}

In gradual oxidation of fat, aldehydes, ketones, acids, and other secondary oxidation products were produced, forming a unique sausage flavour. However, excessive lipid oxidation leads to meat odour [12] and generates malondialdehyde (MDA) and other harmful substances, which greatly affect the quality of meat products. This was the main factor limiting the shelf life of the products. TBARS is the most direct index for evaluating the oxidation of meat products worldwide. 
As shown in Figure 2, the TBARS values of sausages gradually increased, indicating that lipid oxidation occurred. There was no significant difference between the three groups before day $16(p \geq 0.05)$.

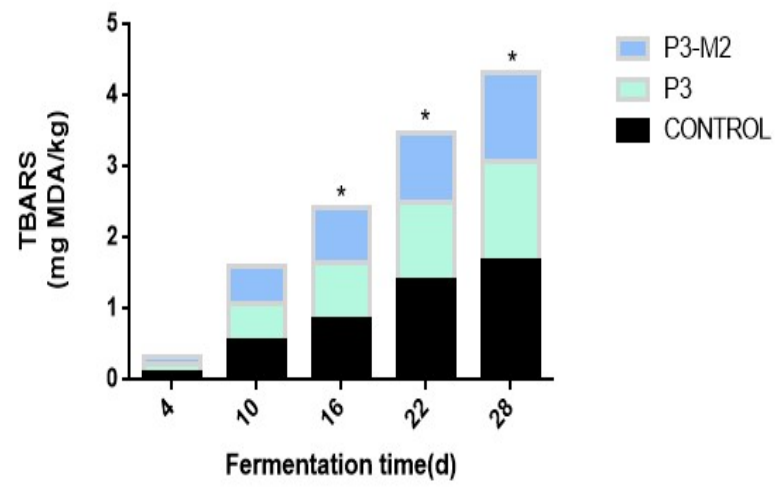

Figure 2. Changes of TBARs values of three groups sausages during fermentation. Data are expressed as the mean of triplicate samples \pm standard error. Vertical bars represent the standard errors of the means. ${ }^{*}$ above the bars indicate statistically significant differences $(p<0.05)$.

On day 4, the TBARS of the three groups was $0.11 \mathrm{mg}$ MDA $/ \mathrm{kg}$. However, On the day 10 the TBARS values of P3 group and P3-M2 group were $0.48 \mathrm{mg} \mathrm{MDA} / \mathrm{kg}$ and 0.50 $\mathrm{mg} \mathrm{MDA} / \mathrm{kg}$ respectively, which were significantly lower than those of control group $(p<$ $0.05)$. After day 10, the TBARS values of the three groups were as follows: P3-M2 group < P3 group $<$ Control group. The lower TBARS values of P3-MS were significantly different $(p<0.05)$ after day 16. At the end of storage, the TBARS values in the P3-M2 group were $1.25 \mathrm{mg} \mathrm{MDA} / \mathrm{kg}$ lower than those in the control and P3 groups $(p<0.05)$. This showed that LAB inhibited the access to sausages with the production of MDA. This was consistent with the results of Libera et al. [28], who reported that the addition of probiotic strain reduced lipid oxidation.

Antioxidants inhibit fat oxidation mainly by scavenging free radicals or chelating metal ions to prevent free radical chain reactions. Strains P3 and P3-M2 have a strong ability to scavenge free radicals, such as DPPH free radicals, hydroxyl free radicals, and superoxide anions, which can achieve the effect of delayed lipid oxidation. The good scavenging activity of lactic acid bacteria against free radicals has also been confirmed in other studies [29]. Di Yu [22] showed that L. plantarum and Staphylococcus simulans inoculated into fermented sausage contributed to the generation of antioxidant peptides and thus exhibited good antioxidant activity.

\subsubsection{Changes of lip oxygenase (LOX) activity}

LOX is an enzyme that catalyses the oxidation of polyunsaturated fatty acids to produce hydroperoxides. It acts on the 1, 4-cis, cis-pentadiene group positions of unsaturated fatty acids to lose protons and form lipid free radicals.

Changes in LOX activity are shown in Figure 3. LOX activity gradually decreased with the extension of fermentation time $(p<0.05)$. The results were consistent with Bian et al. [30] that the early stage of sausage lip oxidation was mainly affected by enzyme oxidation. LOX plays a role in the loss of unsaturated fatty acid protons and the formation of lipid-free radicals. Thus, these free radicals could induce automatic oxidation of fat, whereas in the later stage, the automatic oxidation was mainly caused by free radicals. The LOX activity of sausages in the P3-M2 group was significantly lower than that in the P3 group on day $4(p<0.05)$. The LOX activity of the P3-M2 group sausage was significantly higher than that of the control group and P3 group $(p<0.05)$, indicating that strains P3-M2 had the ability to inhibit LOX activity. 


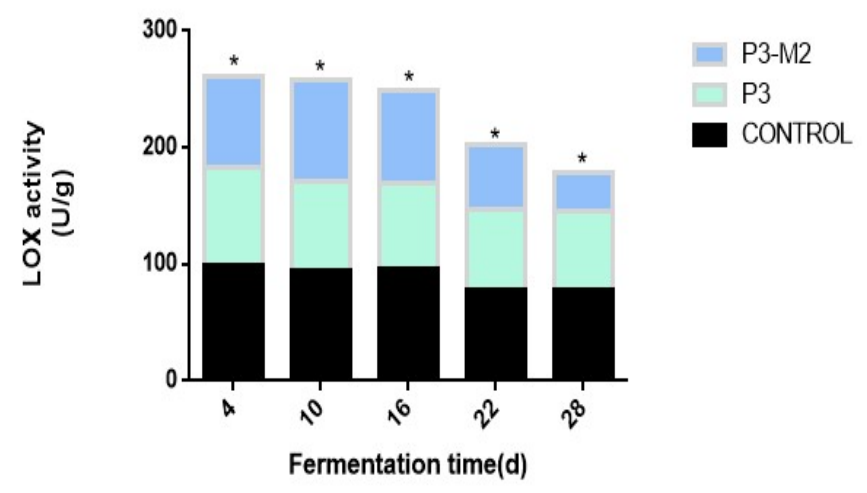

Figure 3. Changes of LOX activity in three groups of sausages of three groups during fermentation. Note: Different capital letters indicate significant differences in LOX activity between the three groups of samples $(p<0.05){ }^{*}{ }^{*}$ indicate significant differences in LOX activity during the same group of fermentation $(p<0.05)$.

Because LOX is an oxidoreductase, it essentially contains non-heme ferritin. The LOX of iron existed in the $\mathrm{Fe}^{2+}$ and $\mathrm{Fe}^{3+}$ states. The $\mathrm{Fe}^{2+}$ state was activated, whereas $\mathrm{Fe}^{3+}$ was the catalytic activity. From the radical scavenging results, it was also found that strain P3-M2 had a strong ability to chelate $\mathrm{Fe}^{2+}$. Therefore, it could be inferred that the strains of $\mathrm{P} 3-\mathrm{M} 2$ could cooperate with $\mathrm{Fe}^{2+}$, maintaining its inactive state to inhibit the activity of LOX.

\subsection{Protein oxidation}

\subsubsection{Carbonyl content}

Carbonyl is the oxidation product of amino acid side chains (such as proline, histidine, lysine, and arginine residues). The carbonyl content is proportional to the degree of protein oxidation [31]. The formation of carbonyl content can affect the nutrition, flavour, and texture of meat products. For example, carbonyl compounds of proteins can form specific Strecker aldehydes, which contribute to the flavour of meat products, but the oxidation of certain amino acids, including essential amino acids, can lead to a decrease in the nutritional value of meat [32].

The changes in the carbonyl content are shown in Figure 4 . After $10 \mathrm{~d}$, the carbonyl content of the P3-M2 group protein was significantly lower than that of the control group $(p<0.05)$ in both the sarcoplasmic protein (Figure 4a) and myofibrillar protein(Figure $4 b$ ), indicating that L. plantarum P3-M2 could reduce the formation of carbonyl groups in the protein. Ge et al. [14] also observed that L. plantarum NJAU-01 could be used as a starter in sausages to reduce carbonyl production during fermentation. 
(a)

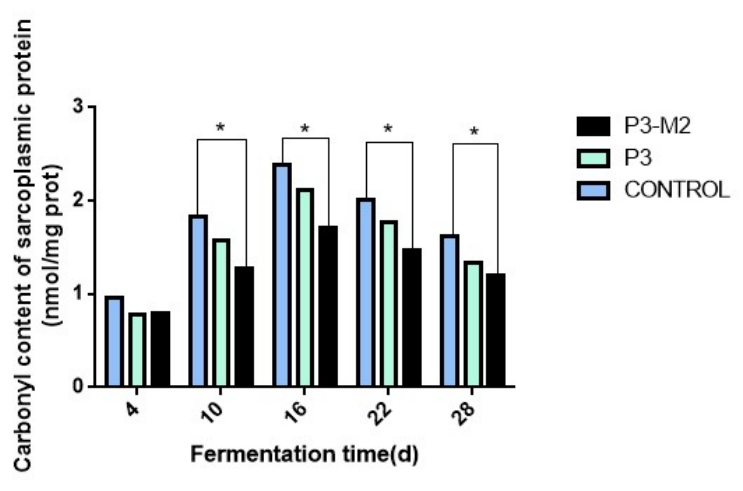

(b)

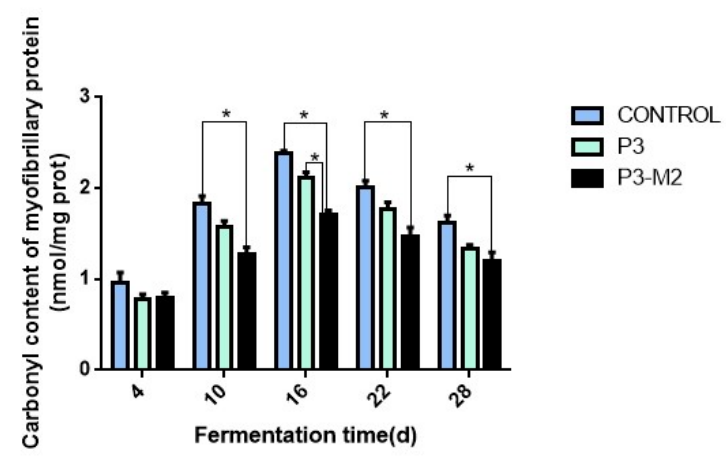

Figure 4. Changes of carbonyl content in sarcoplasmic protein(a) and myofibrillar protein(b) of three groups during fermentation. Data are expressed as the mean of triplicate samples \pm standard error. Vertical bars represent the standard errors of the means. * above the bars indicate statistically significant differences $(p<0.05)$.

The carbonyl content (a) gradually increased on day 10, and decreased significantly after 16 days. This may be because the carbonyl group produced by the oxidation of protein further reacted to form acids or reacted with amino acids to form azomethines. In addition, aldol condensates may also form between the carbonyl molecules.

\subsubsection{Sulfhydryl content}

Oxidation of proteins causes the destruction of sulfhydryl groups to form disulphide bonds, leading to protein cross-linking [33]. The sulfhydryl group content was inversely proportional to the degree of protein oxidation. Therefore, the loss of sulfhydryl groups is also one of the indicators commonly used to evaluate the degree of protein oxidation.

The sulfhydryl content of sarcoplasmic proteins in sausages decreased during $28 \mathrm{~d}$ (Figure 5). After 4 days, the sulfhydryl content of sarcoplasmic protein in the P3-M2 group was significantly higher $(p<0.05)$ than that in the other two groups (Figure5 a, b). Under oxidising conditions, the internal structure of the sausages was unfolded, and the internal sulfhydryl groups were exposed, resulting in increased sulfhydryl content. The changes in the sulfhydryl content of sarcoplasmic protein and myofibril protein showed that the addition of L. plantarum P3-M2 could reduce the loss of protein sulfhydryl groups in sausage and the degree of protein oxidation in sausages. This was consistent with the findings of Zhang et al. [34], indicating that adding rat wort extract to sausage as a natural antioxidant can delay the damage of sulfhydryl groups. 
(a)

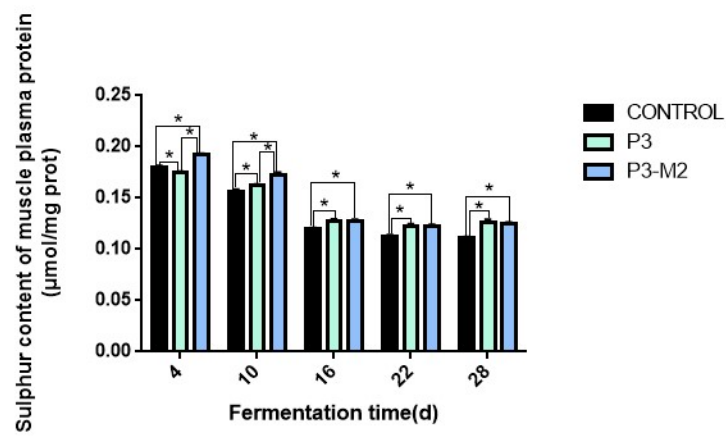

(b)

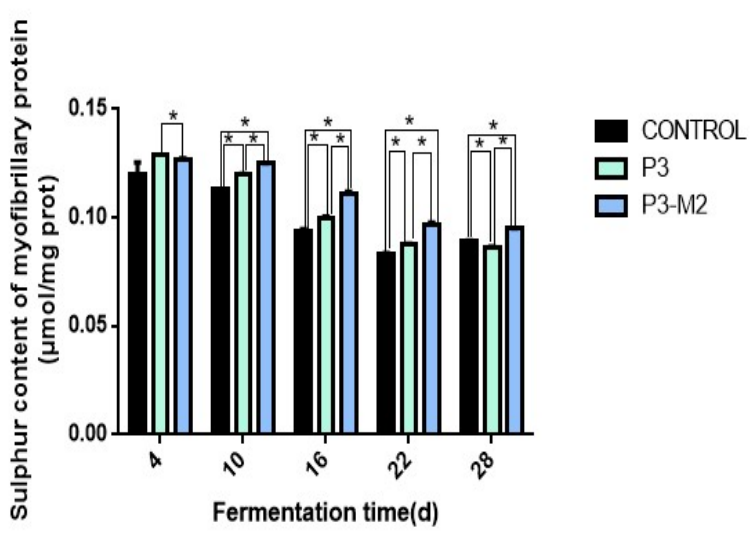

Figure 5. Changes of sulfhydryl group content in sarcoplasmic protein(a) and myofibrillar protein(b) of three groups during fermentation. Data are expressed as the mean of triplicate samples \pm standard error. Vertical bars represent the standard errors of the mean; * above the bars indicate statistically significant differences at $p<0.05$.

\subsubsection{Surface hydrophobicity of myoplasmic protein and myofibrillar protein}

The surface hydrophobicity of sarcoplasin was determined using an ANS fluorescent probe. Myofibrillar protein is a salt-soluble protein, so its surface hydrophobicity was determined using the bromophenol blue method.

The changes in the hydrophobicity of the sausages are shown in Figure 6(a, b). It was found that the surface hydrophobicity gradually increased. With the occurrence of protein oxidation and protein degradation, the protein structure was destroyed, and the hydrophobic amino acids inside the protein were exposed, leading to an increase in surface hydrophobicity. The surface hydrophobicity of the control group in muscle plasma protein was higher than that in the P3 and P3-M2 groups, especially after 10 days $(p<0.05)$. The surface hydrophobicity of the P3-M2 group was significantly lower than that of the other two groups $(p<0.05)$, suggesting that strain P3-M2 could inhibit protein oxidation, which reduced the hydrophobic groups from the degree of protein oxidation, and the addition of the strain reduced the surface hydrophobicity of sausage sarcoplasmic protein, and the protein structure was protected to a certain extent. The hydrophobicity of the P3-M2 group was always the lowest, indicating that the mutant strain $\mathrm{p} 3-\mathrm{M} 2$ could slow down the degree of oxidation of sarcoplasmic protein. 
(a)

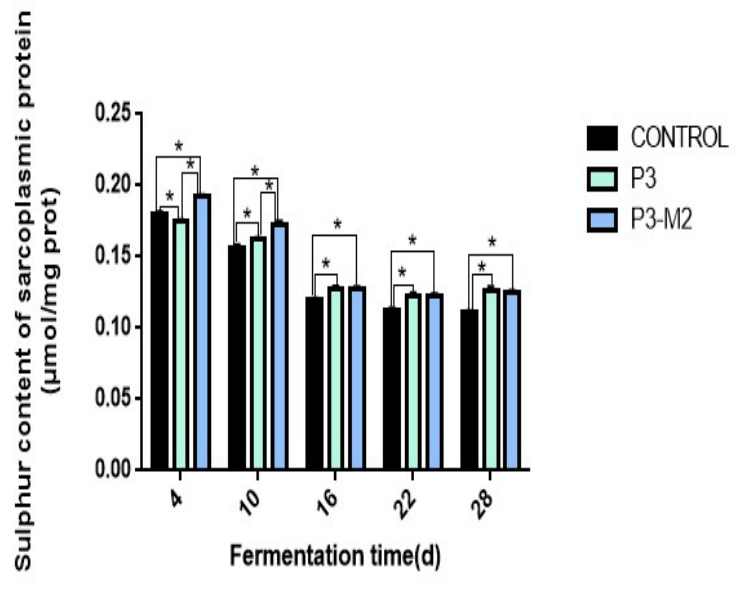

(b)

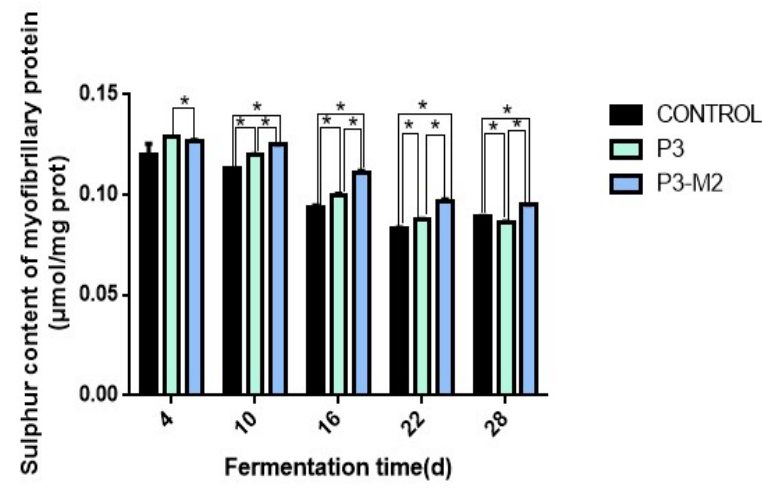

Figure 6. Changes of surface hydrophobicity in sarcoplasmic proteins(a) and myofibrillar protein(b).Different capital letters indicate significant differences in the surface hydrophobicity of sarcoplasmic proteins between the three groups of samples $(p<0.05)$; different lowercase letters indicate significant differences in the surface hydrophobicity of the sarcoplasmic proteins during the same group of fermentation $(p<0.05)$.

\subsection{4 $\alpha$-helix structure changes of myoplasmic protein and myofibrillar protein}

The $\alpha$-helix is mainly a stable hydrogen bond between carbonyl and amino groups generated by the polypeptide chain. Oxidation can lead to a reduced $\alpha$-helix content.

The $\alpha$-helix structure of the sausage is shown in Figure 7. The relative content of $\alpha$-helix showed a tendency to decrease during the fermentation process. Hydrogen bonding between the carbonyl and amino groups is damaged by exposure to the hydrophobic groups of oxidation. Thus, the $\alpha$-helix structure was reduced by peptide bond breakage in the protein [35]. 
(a)
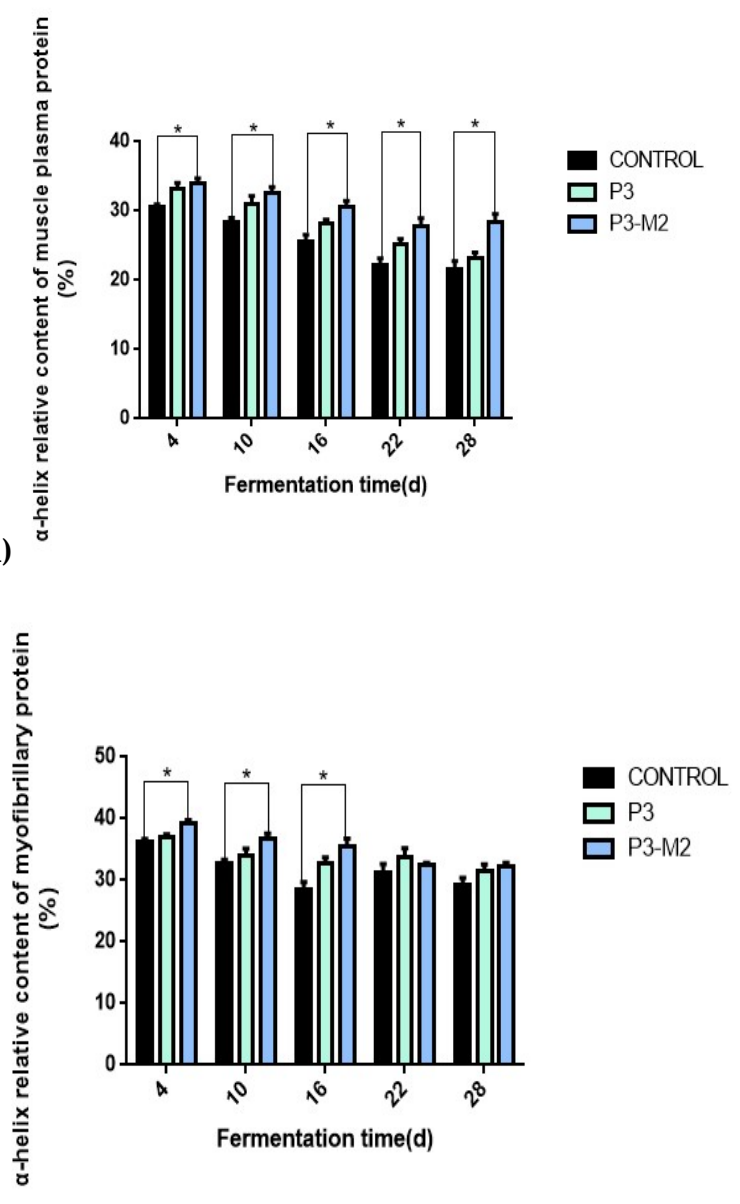

Figure 7. Changes of $\alpha$-helix relative content in sarcoplasmic protein and myofibrillar protein of three groups during fermentation. Different lowercase letters indicate that the relative content of sarcoplasmic protein $\alpha$-helix is significantly different among the three groups of samples $(p<0.05)$, and different lowercase letters indicate that the relative content of sarcoplasmic protein $\alpha$-helix is significantly different during the same group of fermentation $(p<0.05)$.

As the control group of sausage did not add the other ingredients with antioxidant ability, the $4 \mathrm{~d} \alpha$-helix relative content in the control group was lower than that in the other two groups $(p<0.05)$. The relative content of the group P3 $\alpha$-helix structure was lower than that of the P3-M2 group because the antioxidant activity of the P3-M2 strain was stronger than that of the $\mathrm{P} 3$ group.

\subsubsection{MetMb content}

Myoglobin has the function of depositing pigment and exists inside the cells, making the meat appear red. Myoglobin was oxidised to produce oxygenated myoglobin, making the meat appear bright red. Oxymyoglobin can then be further oxidised to form metmyoglobin, making the meat brown.

On the day 10, the MetMb content (Figure 8 ) of the P3-M2 group was significantly lower than that of the control group $(p<0.05)$. The overall MetMb content gradually increased. The MetMb content in the control group was always at the highest level, which also explained that the colour of sausages in the control group changed significantly during the fermentation process $(p<0.05)$. Lactobacillus plantarum P3-M2 was shown to reduce the production of MetMb and the rate of myoglobin oxidation. 


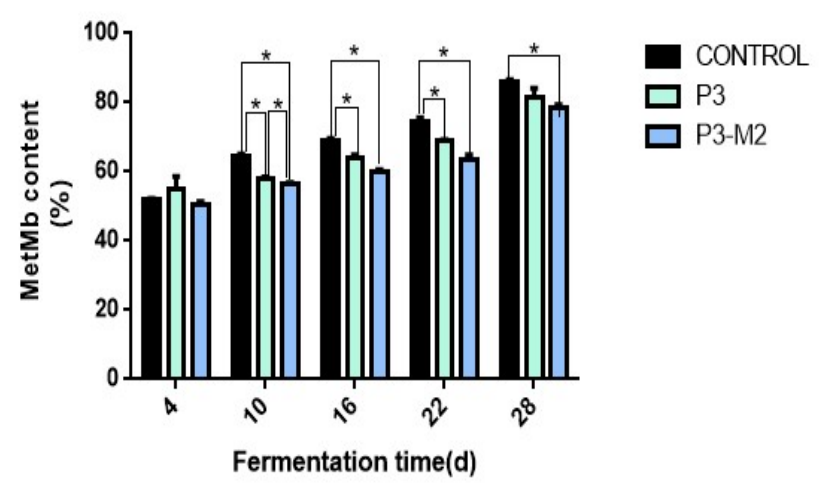

Figure 8. Changes of MetMb content in three groups during fermentation. Data are expressed as the mean of triplicate samples \pm standard error. Vertical bars represent the standard errors of the means. *above the bars indicate statistically significant differences $(p<0.05)$.

\subsubsection{SDS-PAGE of myoplasmic protein and myofibrillar protein}

Protein hydrolysis generates non-volatile substances such as peptides and free amino acids, which play an important role in the flavour of sausage products [36].

As shown in Figure 9(A), the protein bands of sarcoplasmic protein in fermented sausage were much higher, and the difference in molecular weight was small. HMWP was gradually degraded during fermentation, and the protein band strength of the control group was higher than that of the other two groups on the day 28. P3 and P3-M2 play a role in promoting protein degradation during fermentation. SDS-PAGE results of the three groups of sausage sarcoproteins showed that the protein strips between $98 \mathrm{kDa}$ and $180 \mathrm{kDa}$ gradually disappeared, indicating that the high-molecular weight protein was degraded.

The $25 \mathrm{kDa}$ bands, one between $34 \mathrm{kDa}$ protein bands, gradually disappeared with an extended fermentation time and were speculated to be enzymes or peptides with antioxidant activity. Weizheng Sun [37] also reported that the disappeared proteins were related to antioxidant activity. The control group of sarcoplasmic protein electrophoresis in the protein bands at the day 16 has largely disappeared completely, indicating more severe muscle plasma protein oxidation.

The SDS-PAGE bands of the sausage muscle plasma protein of the P3 group largely disappeared on the day 22, while the electrophoresis of the P3-M2 sausage sarcoplasmic protein showed that the protein band was weakened but existed at the day 28 .

The three groups of sausage sarcoplasm protein from 10 to $17 \mathrm{kDa}$ protein bands gradually disappeared. The $14 \mathrm{kDa}$ protein bands may be myoglobin, which can be combined with oxygen and decrease gradually under oxidising conditions. The protein bands between $25 \mathrm{kDa}$ and $34 \mathrm{kDa}$ also gradually disappeared possibly due to creatine kinase.

On the day 22 and 28 , the protein bands mainly concentrated between $34 \mathrm{kDa}$ and greater than 17 to $25 \mathrm{kDa}$. This is because of the degradation of macromolecular proteins and polymerization of small molecular proteins due to the function of endogenous enzymes and enzymes produced by lactic acid bacteria. The large molecular weight protein bands in p3-M2 group were significantly weakened at the day 28, indicating that strain p3-M2 could also promote the hydrolysis of sausage sarcoplasin. With the action of lactic acid bacteria, sarcoplasmic protein will produce hydrophilic polypeptides, the production of hydrophilic polypeptides was conducive to good flavour formation.

As shown in Figure 9(B), the degradation of myofibrillar protein by strains $\mathrm{P} 3$ and P3-M2 was not as significant as that by strains P3 and P3-M2. In the electrophoresis diagram of the three groups of sausage myofibrillar protein, the changes in protein bands were mainly between 98 to $180 \mathrm{kDa}, 62 \mathrm{kDa}$, and 25 to $34 \mathrm{kDa}$. A new protein band 
appeared at $62 \mathrm{kDa}$. The electrophoresis of myofibrillar protein in groups P3 and P3-M2 showed that the high-molecular-weight protein degraded to a low-molecular-weight protein at the day 22 and 28, indicating that strains P3 and P3-M2 had a certain promoting effect on the hydrolysis of myofibrillar protein.

In SDS-PAGE, the degree of hydrolysis of myofibrillary protein and sarcoplasmic protein in the P3-M2 group was higher, which may be due to the small change in protein structure under low oxidation level. However, when proteins are highly oxidised, protein polymers can be formed, and some special amino acid side chains can also be oxidised, leading to reduced protease recognition sites, thus decreasing the degree of protein hydrolysis [38].
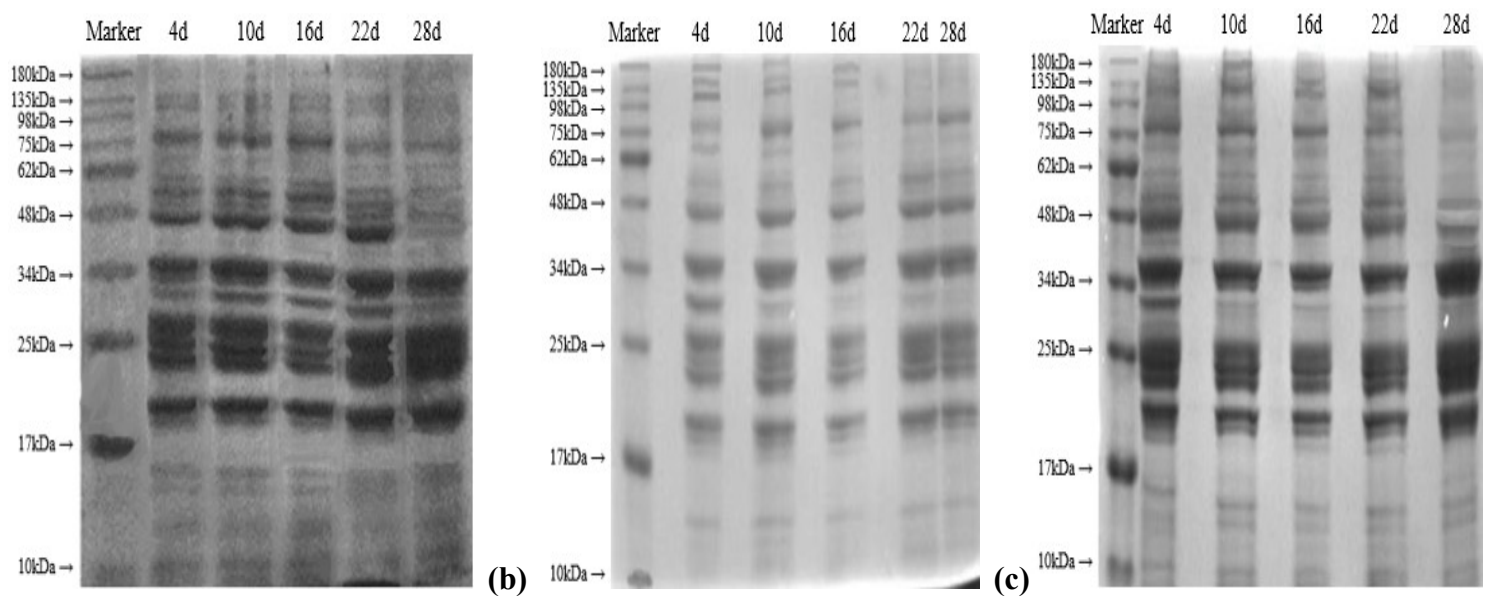

Figure 9(A). SDS-PAGE electrophoresis of sarcoplasmic protein in sausage on the day 4, 10, 16, 22 and 28. (A) (a is CK group, b is P3 group, and c is $\mathrm{P} 3-\mathrm{M} 2$ group).
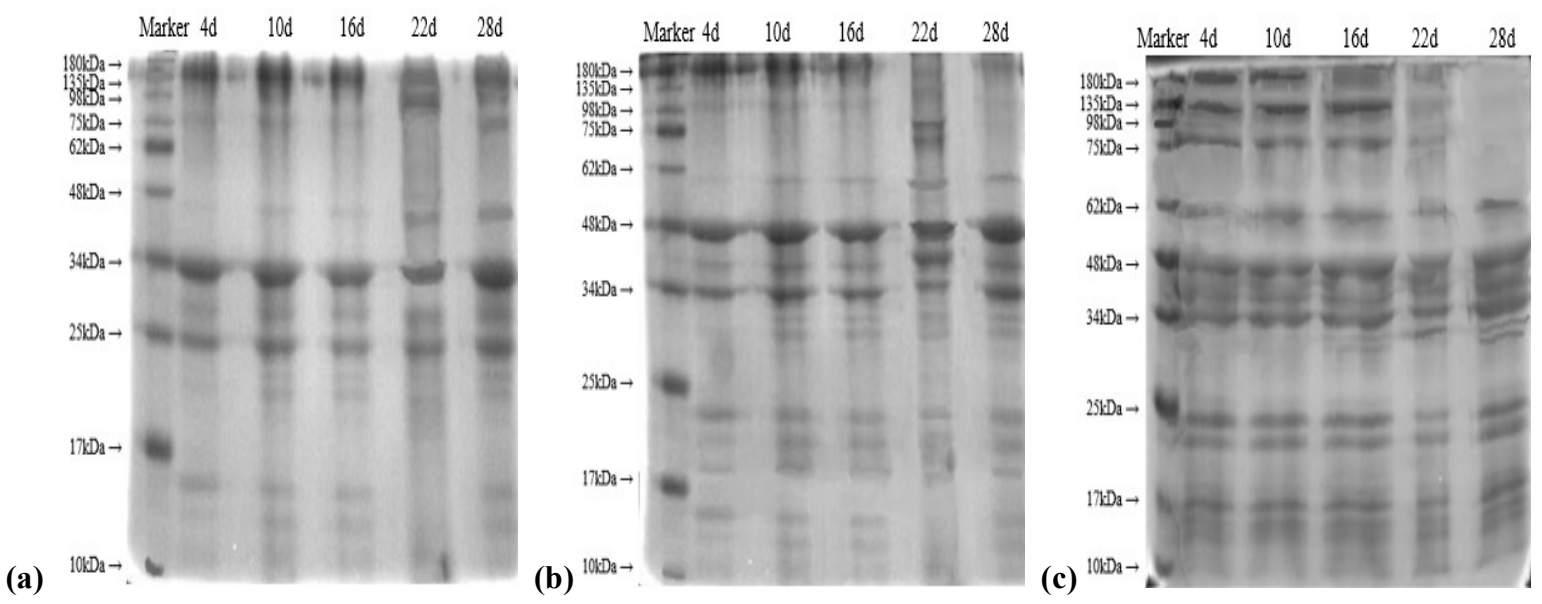

Figure 9(B). SDS-PAGE electrophoresis of myofibrillar protein in sausage (B) on the day 4, 10, 16, 22 and 28. (a is CK group, b is P3 group, and c is P3-M2 group).

\subsection{Volatile compounds}

The flavour of fermented meat products is caused by the production and accumulation of volatile and non-volatile aromatic compounds and other flavour-related compounds, such as alcohols, aldehydes, ketones, and esters. Proteins, carbohydrates, and lipids are the precursors of aromatic compounds [39]. The oxidation of lipids and proteins in meat products produces ketones, aldehydes, and other substances that directly affect their taste and flavour. Lactic acid bacteria can use carbohydrates, proteins, 
organic acids, amino acids, and other nutrients to produce volatile and non-volatile flavour compounds.

The results of volatile substances and their relative percentages are shown in Figure 10 and Table 1 . A total of 153 volatile substances were detected by GC-MS. The relative contents of total esters increased by $53.43 \%$ and $48.67 \%$. The relative contents of total alcohols decreased by $30.27 \%$ and $48.52 \%$. The relative contents of total aldehydes decreased by $8.83 \%$ and $32.92 \%$. Total acid decreased $8.98 \%$ and $32.67 \%$. Ketones decreased $2.07 \%$ and $8.97 \%$. And total terpenes decreased $25.92 \%$ and $32.84 \%$.

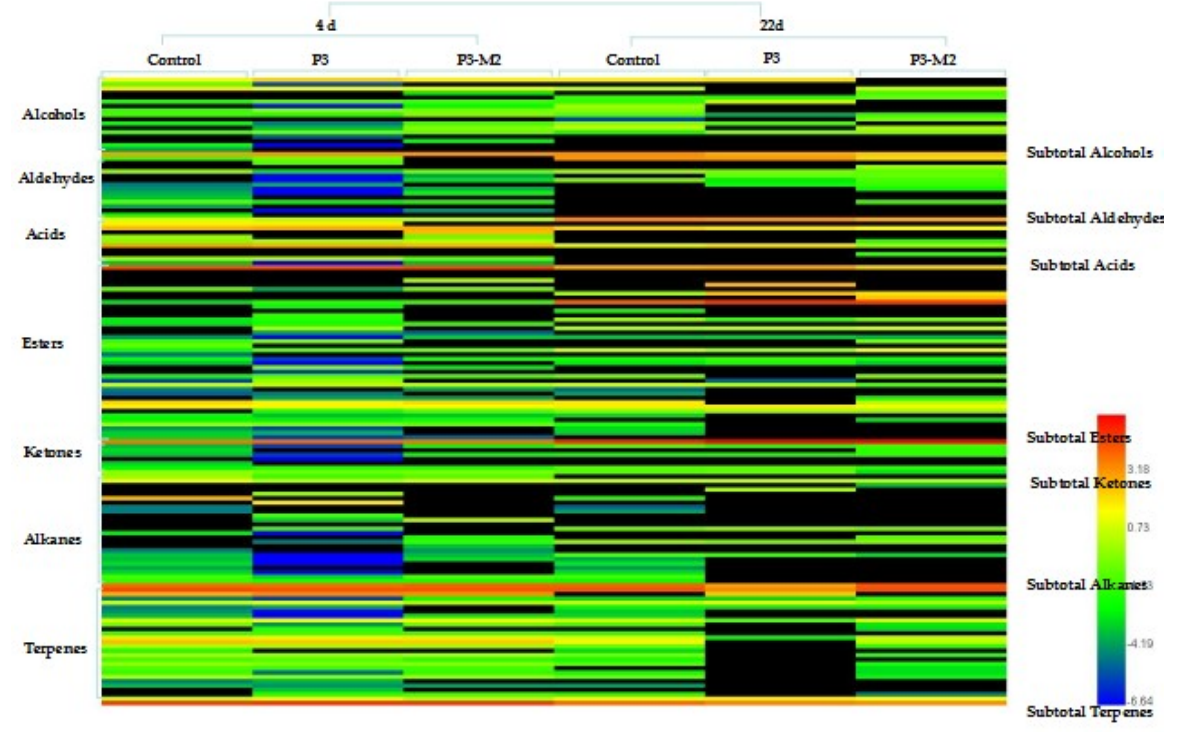

Figure 10. Changes of relative content of volatile substances in control sausage(a), P3(b) and P3-M2(c) on the day 4 and 22.

Table 1. Concentration of volatile compounds in three groups sausages on the day 4 and 22. (\%).

\begin{tabular}{|c|c|c|c|c|c|c|c|}
\hline & & & & & & & \\
\hline & & & & & & & \\
\hline RT(min) & Compouds & control & P3 & P3-M2 & control & P3 & P3-M2 \\
\hline 4.869 & Ethyl alcohol & $2.69 \pm 0.34$ & $4.91 \pm 0.51$ & $3.52 \pm 1.29$ & $3.57 \pm 1.73$ & $4.17 \pm 2.33$ & - \\
\hline 9.589 & N-pentanol & $0.48 \pm 0.03$ & $0.02 \pm 0.01$ & - & - & - & - \\
\hline 10.98 & 2,3-butanediol & $3.74 \pm 0.42$ & $2.5 \pm 0.15$ & $2.37 \pm 1.04$ & $1.34 \pm 1.05$ & - & $1.6 \pm 1.14$ \\
\hline 16.738 & Cineole & - & - & $0.14 \pm 0.06$ & - & - & $0.35 \pm 0.06$ \\
\hline 17.414 & 1-Octen-3-ol & - & - & - & $0.32 \pm 0.05$ & $0.26 \pm 0.01$ & $0.53 \pm 0.11$ \\
\hline 18.967 & eucalyptol & $0.23 \pm 0.07$ & $0.44 \pm 0.12$ & $0.34 \pm 0.21$ & $0.29 \pm 0.06$ & $1.73 \pm 1.13$ & - \\
\hline 19.027 & Benzyl alcohol & - & $0.01 \pm 0.01$ & $0.17 \pm 0.09$ & $1.1 \pm 0.74$ & - & - \\
\hline 20.462 & Linalool & $0.34 \pm 0.11$ & $0.78 \pm 0.18$ & $0.73 \pm 0.25$ & $0.76 \pm 0.16$ & - & - \\
\hline 20.886 & $\begin{array}{c}\text { phenylethyl } \\
\text { alcohol }\end{array}$ & $0.35 \pm 0.09$ & $0.26 \pm 0.15$ & $0.74 \pm 0.04$ & $0.44 \pm 0.22$ & $0.07 \pm 0.03$ & $0.32 \pm 0.12$ \\
\hline 22.048 & 2-camphanol & - & - & - & $0.02 \pm 0.01$ & - & $0.62 \pm 0.09$ \\
\hline 22.061 & d-borneol & $0.18 \pm 0.07$ & $0.04 \pm 0.02$ & $0.35 \pm 0.08$ & $0.78 \pm 0.04$ & $0.37 \pm 0.14$ & - \\
\hline 22.204 & 4-terpineol & - & $0.08 \pm 0.04$ & $0.77 \pm 0.21$ & $1.65 \pm 1.11$ & - & $1.2 \pm 1.13$ \\
\hline 22.432 & alpha terpineol & $0.35 \pm 0.12$ & $0.56 \pm 0.10$ & $0.55 \pm 0.09$ & $0.21 \pm 0.14$ & $0.7 \pm 0.03$ & $0.76 \pm 0.07$ \\
\hline
\end{tabular}




\begin{tabular}{|c|c|c|c|c|c|c|c|}
\hline 25.409 & 1-Tetradecanol & - & $0.03 \pm 0.01$ & - & - & - & - \\
\hline 28.003 & 1-Tridecanol & - & - & $0.15 \pm 0.07$ & - & - & - \\
\hline 28.005 & 1-Hexadecanol & $0.17 \pm 0.21$ & $0.01 \pm 0.01$ & - & - & - & - \\
\hline \multirow[t]{2}{*}{29.361} & 6-Apigenin-4-ol & $0.06 \pm 0.04$ & - & - & - & - & - \\
\hline & Subtotals (\%) & $8.69 \pm 3.50 \mathrm{~A}$ & $9.65 \pm 2.31 \mathrm{~A}$ & $9.84 \pm 2.15 \mathrm{~A}$ & $10.47 \pm 1.50 \mathrm{~A}$ & $7.3 \pm 2.14 \mathrm{~A}$ & $5.39 \pm 1.10 \mathrm{~B}$ \\
\hline 11.291 & hexanal & $0.32 \pm 0.05$ & $0.61 \pm 0.10$ & - & $9.56 \pm 3.16$ & $8.84 \pm 2.23$ & $4.4 \pm 2.17$ \\
\hline 16.73 & 2-Heptenal & - & $0.44 \pm 0.12$ & - & - & - & - \\
\hline 16.989 & (E)-2-heptenal & - & - & - & - & - & $0.92 \pm 0.23$ \\
\hline 18.062 & benzaldehyde & $0.95 \pm 0.07$ & $0.13 \pm 0.05$ & $0.6 \pm 0.14$ & $1.05 \pm 0.10$ & $0.65 \pm 0.21$ & $0.48 \pm 0.09$ \\
\hline 19.242 & n-octanal & - & $0.01 \pm 0.03$ & $0.06 \pm 0.03$ & - & $0.53 \pm 0.07$ & $0.53 \pm 0.11$ \\
\hline 19.494 & $\begin{array}{c}\text { phenylacetaldehy } \\
\text { de }\end{array}$ & - & $0.01 \pm 0.01$ & $0.13 \pm 0.06$ & $0.72 \pm 0.18$ & $0.14 \pm 0.03$ & $0.38 \pm 0.14$ \\
\hline 21.682 & trans-2-octenal & $0.04 \pm 0.02$ & $0.07 \pm 0.05$ & - & - & $0.17 \pm 0.11$ & $0.33 \pm 0.09$ \\
\hline 23.507 & trans-2-nonanal & $0.05 \pm 0.04$ & $0.01 \pm 0.01$ & $0.07 \pm 0.05$ & - & - & $0.2 \pm 0.09$ \\
\hline 23.569 & $\begin{array}{l}\text { Trans-2-decene } \\
\text { aldehyde }\end{array}$ & $0.07 \pm 0.05$ & $0.01 \pm 0.01$ & $0.19 \pm 0.03$ & - & - & - \\
\hline 23.841 & p-tolualdehyde & $0.09 \pm 0.07$ & - & - & - & - & - \\
\hline 25.183 & $\begin{array}{c}\text { trans-cinnamalde } \\
\text { hyde }\end{array}$ & $0.49 \pm 0.14$ & $0.17 \pm 0.09$ & $0.26 \pm 0.08$ & - & - & $0.37 \pm 0.15$ \\
\hline 30.586 & $\gamma$-nonalactone & $0.06 \pm 0.04$ & - & - & - & - & - \\
\hline 30.585 & pentadecanal & - & $0.01 \pm 0.04$ & $0.05 \pm 0.02$ & - & - & - \\
\hline \multirow[t]{2}{*}{11.291} & hexadecanal & $0.18 \pm 0.08$ & - & - & - & - & - \\
\hline & Subtotals（\%） & $2.25 \pm 1.22 \mathrm{~A}$ & $1.45 \pm 0.94 \mathrm{~A}$ & $1.37 \pm 1.43 \mathrm{~A}$ & $11.33 \pm 2.98 \mathrm{~A}$ & $10.33 \pm 2.52 \mathrm{~A}$ & $7.60 \pm 2.31 \mathrm{~A}$ \\
\hline 6.522 & oxalic acid & $3.46 \pm 1.13$ & $3.55 \pm 1.32$ & - & - & - & - \\
\hline 10.048 & acetic acid & $6.28 \pm 1.47 \mathrm{~A}$ & $7.15 \pm 1.37 \mathrm{~A}$ & $7.32 \pm 0.21 \mathrm{~A}$ & $4.63 \pm 0.95 \mathrm{~A}$ & $3.83 \pm 0.48 \mathrm{~A}$ & $3.1 \pm 0.09 \mathrm{~B}$ \\
\hline 10.891 & $\begin{array}{c}\text { 3-methyl } \\
\text { pentanoic acid }\end{array}$ & - & - & $6.36 \pm 2.56$ & - & - & - \\
\hline 11.372 & $\begin{array}{l}\text { 3-methyl butyric } \\
\text { acid }\end{array}$ & $0.97 \pm 0.07$ & 0 & $0.53 \pm 0.32$ & - & - & - \\
\hline 11.455 & $\begin{array}{l}\text { 2-methyl butyric } \\
\text { acid }\end{array}$ & $0.77 \pm 0.09$ & $1.08 \pm 0.21$ & $1.39 \pm 0.16$ & - & - & $0.27 \pm 0.16$ \\
\hline 13.124 & n-caproic acid & $8.27 \pm 2.43$ & $7.06 \pm 2.27$ & $6.56 \pm 1.15$ & $2.39 \pm 1.25$ & $3.81 \pm 1.27$ & $1.07 \pm 0.96$ \\
\hline 14.676 & $\begin{array}{c}\text { (s)-(+)-ma0elic } \\
\text { acid }\end{array}$ & - & - & - & - & - & $0.28 \pm 0.04$ \\
\hline 17.913 & caprylic acid & $1.19 \pm 0.18$ & $1.29 \pm 0.37$ & $0.52 \pm 0.11$ & - & - & - \\
\hline 19.031 & $\begin{array}{c}\text { 3-methylbut-2-en } \\
\text { oic acid }\end{array}$ & $0.09 \pm 0.04$ & $0.01 \pm 0.02$ & $0.08 \pm 0.05$ & - & - & - \\
\hline 19.49 & Subtotals（\%） & $21.02 \pm 3.41 \mathrm{~A}$ & $20.14 \pm 2.97 A$ & $22.75 \pm 2.53 \mathrm{~A}$ & $7.01 \pm 3.37 \mathrm{~A}$ & $7.64 \pm 2.51 \mathrm{~A}$ & $4.72 \pm 2.78 \mathrm{~A}$ \\
\hline 19.758 & ethyl isobutyrate & - & - & $1.22 \pm 1.02$ & - & - & - \\
\hline 20.327 & ethyl lactate & - & - & - & - & $6.7 \pm 2.35$ & - \\
\hline 20.42 & Cinnamicacid & $0.52 \pm 0.32$ & $0.07 \pm 0.05$ & $0.66 \pm 0.29$ & - & - & - \\
\hline
\end{tabular}




\begin{tabular}{|c|c|c|c|c|c|c|c|}
\hline & vinylester & & & & & & \\
\hline \multirow[t]{2}{*}{20.46} & $\begin{array}{c}\text { Ethyl } \\
\text { 3-methylbutyrate }\end{array}$ & - & - & - & $0.97 \pm 0.10$ & $6.46 \pm 2.44$ & $4.16 \pm 1.01$ \\
\hline & Benzoic & & & & & & \\
\hline 20.683 & $\begin{array}{c}\text { acid-2-phenyleth } \\
\text { yl ester }\end{array}$ & - & - & - & - & - & $5.47 \pm 0.32$ \\
\hline 21.986 & ethyl hexanoate & $0.13 \pm 0.06 \mathrm{~A}$ & $0.28 \pm 0.09 \mathrm{~A}$ & $0.35 \pm 0.06 B$ & $16.57 \pm 2.77 \mathrm{~A}$ & $27.41 \pm 3.25 B$ & $26.48 \pm 3.86 \mathrm{~B}$ \\
\hline 22.188 & $\begin{array}{c}\text { Ethyl } \\
\text { DL-Ma0elate }\end{array}$ & - & $0.17 \pm 0.07$ & - & - & - & - \\
\hline 22.212 & $\begin{array}{c}\text { Decyl } \\
\text { methacrylate }\end{array}$ & - & - & - & $0.22 \pm 0.06$ & - & - \\
\hline 22.291 & octyl formate & - & $0.29 \pm 0.11$ & - & - & - & - \\
\hline 22.91 & ethyl heptylate & $0.14 \pm 0.09$ & $0.26 \pm 0.15$ & - & $0.85 \pm 0.17$ & $0.29 \pm 0.11$ & $0.59 \pm 0.13$ \\
\hline 23.018 & $\begin{array}{l}\text { 3-methylbutyl-2- } \\
\text { methylbutyrate }\end{array}$ & $0.13 \pm 0.07$ & $0.2 \pm 0.13$ & $0.33 \pm 0.13$ & - & - & - \\
\hline 23.228 & linalyl formate & - & $1.25 \pm 0.15$ & - & $1.05 \pm 0.9$ & $1.22 \pm 0.15$ & $1.59 \pm 0.43$ \\
\hline 23.27 & $\begin{array}{c}\text { Butane-2-yl-3-me } \\
\text { thylbutyrate }\end{array}$ & - & $0.06 \pm 0.03$ & $0.03 \pm 0.01$ & - & - & - \\
\hline 23.959 & ethyl benzoate & $0.05 \pm 0.04$ & $0.01 \pm 0.01$ & $0.1 \pm 0.06$ & $0.09 \pm 0.04$ & $0.1 \pm 0.05$ & $0.07 \pm 0.05$ \\
\hline 24.529 & butyl caproate & $0.33 \pm 0.19$ & $0.6 \pm 0.24$ & - & - & - & $0.6 \pm 0.32$ \\
\hline 24.53 & $\begin{array}{l}\text { butyric acid } \\
\text { hexylester }\end{array}$ & $0.57 \pm 0.25$ & - & - & - & - & - \\
\hline 24.951 & ethyl ocanoate & $0.19 \pm 0.07$ & $0.43 \pm 0.13$ & $0.53 \pm 0.32$ & $1.56 \pm 0.23$ & $0.91 \pm 0.14$ & $2.41 \pm 1.45$ \\
\hline 24.977 & $\begin{array}{l}\text { 2-ethylhexyl } \\
\text { acrylate }\end{array}$ & $0.03 \pm 0.03$ & - & - & - & - & - \\
\hline 25.181 & hexyl isovalerate & $0.19 \pm 0.13$ & $0.02 \pm 0.01$ & $0.2 \pm 0.11$ & $0.21 \pm 0.09$ & $0.3 \pm 0.16$ & $0.2 \pm 0.09$ \\
\hline 25.317 & $\begin{array}{c}\text { isoamyl caproate } \\
\text { Hexanoic }\end{array}$ & $0.09 \pm 0.04$ & $0.01 \pm 0.01$ & - & $0.14 \pm 0.07$ & $0.23 \pm 0.14$ & $0.1 \pm 0.07$ \\
\hline 25.339 & $\begin{array}{c}\text { acid,2-methylbut } \\
\text { yl ester }\end{array}$ & - & $0.8 \pm 0.37$ & $0.15 \pm 0.08$ & - & - & - \\
\hline 25.432 & n-decyl formate & - & $0.02 \pm 0.01$ & - & - & - & - \\
\hline 26.055 & ethylnonanoate & $0.22 \pm 0.10$ & $0.45 \pm 0.21$ & $0.39 \pm 0.12$ & $0.63 \pm 0.24$ & - & $0.72 \pm 0.32$ \\
\hline 26.626 & $\begin{array}{c}\text { 2-Butenoic } \\
\text { acid,2-methyl-,2- } \\
\text { methylpropyl } \\
\text { ester,(2E)- }\end{array}$ & $0.02 \pm 0.01$ & $0.92 \pm 0.06$ & - & - & $0.03 \pm 0.03$ & - \\
\hline & (E)-hexyl & & & & & & \\
\hline 27.886 & $\begin{array}{c}\text { 2-Methylbut-2-en } \\
\text { oate }\end{array}$ & $1.58 \pm 0.97$ & $1.41 \pm 0.99$ & $1.28 \pm 0.26$ & $1.63 \pm 0.16$ & $1.3 \pm 0.09$ & $0.36 \pm 0.11$ \\
\hline 29.318 & $\begin{array}{c}\text { Ethyl3-phenylpro } \\
\text { pionate }\end{array}$ & $0.04 \pm 0.03$ & - & $0.06 \pm 0.03$ & $0.03 \pm 0.02$ & - & - \\
\hline
\end{tabular}




\begin{tabular}{|c|c|c|c|c|c|c|c|}
\hline 30.272 & terpinyl acetate & $0.03 \pm 0.03$ & $0.04 \pm 0.02$ & - & $0.06 \pm 0.04$ & - & - \\
\hline 32.303 & $\begin{array}{c}\text { 4-hydroxydecano } \\
\text { ic acid }\end{array}$ & - & $0.06 \pm 0.04$ & $0.06 \pm 0.01$ & - & - & $0.21 \pm 0.10$ \\
\hline 6.522 & hexyl caproate & $4.47 \pm 1.98$ & $3.36 \pm 1.84$ & $4.41 \pm 1.07$ & $3.57 \pm 1.28$ & - & $1.46 \pm 0.16$ \\
\hline 10.048 & n-butyl octanoate & $3.33 \pm 1.39$ & $3.25 \pm 1.99$ & $2.98 \pm 1.37$ & $3.64 \pm 1.32$ & $3.79 \pm 1.11$ & $2.8 \pm 0.98$ \\
\hline 10.891 & ethyl caprate & - & $0.23 \pm 0.16$ & $0.42 \pm 0.18$ & $0.72 \pm 0.21$ & $1.07 \pm 0.05$ & $0.92 \pm 0.35$ \\
\hline 11.372 & $\begin{array}{l}\text { 2-Hexenoic acid, } \\
\text { butyl ester, (2E)- }\end{array}$ & $0.17 \pm 0.09$ & $0.08 \pm 0.04$ & $0.09 \pm 0.05$ & $0.11 \pm 0.03$ & - & - \\
\hline 11.455 & ethyl cinnamate & $0.16 \pm 0.07$ & $0.16 \pm 0.08$ & $0.2 \pm 0.13$ & - & - & $0.14 \pm 0.06$ \\
\hline 13.124 & hexyl octanoate & $0.93 \pm 0.21$ & $0.73 \pm 0.31$ & $0.52 \pm 0.17$ & $0.22 \pm 0.06$ & - & - \\
\hline 14.676 & $\begin{array}{l}\text { (Z)-dihydro-5-(2- } \\
\text { octenyl)furan-2(3 } \\
\text { H)-one }\end{array}$ & $0.05 \pm 0.03$ & $0.02 \pm 0.02$ & - & $0.11 \pm 0.10$ & - & - \\
\hline 17.913 & $\begin{array}{c}\text { Ethyl hydride } \\
\text { myristate }\end{array}$ & $0.1 \pm 0.09$ & $0.08 \pm 0.04$ & - & $0.1 \pm 0.04$ & - & - \\
\hline \multirow[t]{2}{*}{19.031} & ethyl palmitate & $0.11 \pm 0.03$ & $0.02 \pm 0.02$ & $0.03 \pm 0.02$ & - & - & - \\
\hline & Subtotals (\%) & $13.58 \pm 3.43 \mathrm{~A}$ & $15.28 \pm 2.45 \mathrm{~A}$ & $14.03 \pm 3.02 \mathrm{~A}$ & $32.47 \pm 3.11 \mathrm{~A}$ & $49.82 \pm 3.90 B$ & $48.27 \pm 4.24 B$ \\
\hline 17.607 & $\begin{array}{c}\text { 6-Methyl-5-hepte } \\
\text { n-2-one }\end{array}$ & $0.08 \pm 0.06$ & $0.02 \pm 0.02$ & $0.16 \pm 0.10$ & $0.36 \pm 0.12$ & $0.22 \pm 0.16$ & $0.33 \pm 0.14$ \\
\hline 19.817 & acetophenone & $0.12 \pm 0.07$ & - & - & - & - & $0.29 \pm 0.12$ \\
\hline 20.237 & 2-nonanone & $0.09 \pm 0.04$ & $0.02 \pm 0.02$ & $0.19 \pm 0.03$ & $0.21 \pm 0.14$ & $0.22 \pm 0.97$ & $0.29 \pm 0.16$ \\
\hline 23.981 & 2-U0ecanone & - & $0.01 \pm 0.01$ & - & - & - & - \\
\hline 23.99 & 2-u0ecanone & $0.11 \pm 0.07$ & - & - & - & - & - \\
\hline 24.417 & $\begin{array}{l}\text { 2-isopropyl-5-me } \\
\text { thyl-3-cyclohexen } \\
\text {-1-one }\end{array}$ & $0.16 \pm 0.13$ & $0.25 \pm 0.08$ & $0.24 \pm 0.12$ & $0.43 \pm 0.07$ & $0.46 \pm 0.09$ & $0.28 \pm 0.07$ \\
\hline 27.08 & Apitanedienone & $0.9 \pm 0.11$ & $0.63 \pm 0.15$ & $0.73 \pm 0.09$ & $0.45 \pm 0.11$ & $0.52 \pm 0.07$ & $0.13 \pm 0.02$ \\
\hline \multirow[t]{2}{*}{30.995} & (+)-Cyperone & $0.88 \pm 0.22$ & $0.32 \pm 0.07$ & $0.41 \pm 0.03$ & - & - & - \\
\hline & Subtotals $(\%)$ & $2.34 \pm 1.75 \mathrm{~A}$ & $1.25 \pm 0.69 \mathrm{~A}$ & $1.73 \pm 0.89 \mathrm{~A}$ & $1.45 \pm 0.13 \mathrm{~A}$ & $1.42 \pm 0.67 \mathrm{~A}$ & $1.32 \pm 0.95 \mathrm{~A}$ \\
\hline 3.527 & $\begin{array}{l}\text { Diethanolic } \\
\text { anhydride }\end{array}$ & - & - & - & - & - & $0.08 \pm 0.06$ \\
\hline 4.704 & $\begin{array}{l}\text { ammonium } \\
\text { carbamate }\end{array}$ & - & - & - & - & $1.06 \pm 0.21$ & - \\
\hline 4.808 & formamide & - & $0.85 \pm 0.15$ & - & - & - & - \\
\hline 6.321 & $\begin{array}{l}\text { methoxyacetic } \\
\text { anhydride }\end{array}$ & $5.99 \pm 2.46$ & - & - & $0.27 \pm 0.11$ & - & - \\
\hline 6.478 & $\begin{array}{c}\text { ammonium } \\
\text { acetate }\end{array}$ & - & $3.86 \pm 1.78$ & - & - & - & - \\
\hline 9.721 & $\begin{array}{c}\text { Methanesulfonic } \\
\text { anhydride }\end{array}$ & $0.04 \pm 0.03$ & - & - & $0.03 \pm 0.02$ & - & - \\
\hline 13.016 & formhydrazide & $0.04 \pm 0.04$ & - & - & $0.06 \pm 0.04$ & - & - \\
\hline
\end{tabular}




\begin{tabular}{|c|c|c|c|c|c|c|c|}
\hline 13.145 & $\begin{array}{c}\text { valerate } \\
\text { anhydride }\end{array}$ & - & $0.36 \pm 0.12$ & - & - & - & - \\
\hline 15.261 & $\begin{array}{c}\text { 2-Oxime-2-metho } \\
\text { xy-phenyl }\end{array}$ & - & $0.1 \pm 0.07$ & $1.35 \pm 0.19$ & - & - & - \\
\hline 15.331 & $\begin{array}{l}\text { 2-Methylpentano } \\
\text { ic anhydride }\end{array}$ & - & $0.37 \pm 0.21$ & - & $0.61 \pm 0.28$ & $0.92 \pm 0.14$ & $0.69 \pm 0.12$ \\
\hline 17.488 & $\begin{array}{l}\text { n-Hexanoic } \\
\text { anhydride }\end{array}$ & $0.14 \pm 0.08$ & $0.01 \pm 0.01$ & - & - & - & - \\
\hline 17.52 & $\begin{array}{c}\text { 2,3,5-trimethylpy } \\
\text { razine }\end{array}$ & - & - & $0.23 \pm 0.13$ & - & - & $0.42 \pm 0.13$ \\
\hline 18.104 & butylbenzene & - & $0.04 \pm 0.02$ & $0.32 \pm 0.17$ & $0.95 \pm 0.32$ & $0.68 \pm 0.25$ & $0.78 \pm 0.27$ \\
\hline 18.76 & $\begin{array}{c}\text { pentylcyclopropa } \\
\text { ne }\end{array}$ & - & - & $0.09 \pm 0.04$ & - & - & - \\
\hline 19.49 & $\begin{array}{c}\text { 2-ethyl-3,6-dimet } \\
\text { hylpyrazine }\end{array}$ & $0.04 \pm 0.01$ & - & $0.05 \pm 0.04$ & - & - & - \\
\hline 20.03 & ligustrazine & $0.09 \pm 0.03$ & $0.01 \pm 0.01$ & $0.08 \pm 0.04$ & $0.38 \pm 0.14$ & $0.29 \pm 0.05$ & $0.11 \pm 0.08$ \\
\hline 20.201 & $\begin{array}{c}\text { 1-ethenyl-3,5-dim } \\
\text { ethyl-benzene }\end{array}$ & $0.08 \pm 0.04$ & $0.01 \pm 0.01$ & $0.12 \pm 0.07$ & $0.06 \pm 0.04$ & - & - \\
\hline 20.33 & n-tridecane & $0.12 \pm 0.09$ & $0.01 \pm 0.01$ & - & $0.14 \pm 0.10$ & - & - \\
\hline 24.036 & $\begin{array}{c}\text { 2-methylnaphtha } \\
\text { lene }\end{array}$ & $0.06 \pm 0.02$ & - & - & $0.05 \pm 0.02$ & - & - \\
\hline 24.659 & $\begin{array}{c}\text { 7-methylheptade } \\
\text { cane }\end{array}$ & $0.11 \pm 0.07$ & $0.01 \pm 0.01$ & - & $0.12 \pm 0.06$ & - & - \\
\hline 25.095 & Cyclotetradecane & $0.35 \pm 0.13$ & $0.11 \pm 0.07$ & $0.39 \pm 0.13$ & $0.38 \pm 0.13$ & - & - \\
\hline 25.404 & n-tetradecane & $0.29 \pm 0.21$ & $0.21 \pm 0.12$ & $0.22 \pm 0.07$ & $0.18 \pm 0.05$ & - & - \\
\hline \multirow[t]{2}{*}{25.506} & anethole & $15.65 \pm 1.74$ & $14.98 \pm 1.99$ & $17.03 \pm 1.06$ & $17.26 \pm 2.21$ & $8.11 \pm 1.87$ & $19.34 \pm 1.14$ \\
\hline & Subtotals $(\%)$ & $22.99 \pm 3.76 \mathrm{~A}$ & $20.3 \pm 2.78 \mathrm{~A}$ & $19.96 \pm 2.54 \mathrm{~A}$ & $20.49 \pm 3.08 \mathrm{~A}$ & $11.07 \pm 2.33 B$ & $21.43 \pm 2.07 \mathrm{~A}$ \\
\hline 14.665 & styrene & $7.03 \pm 3.22$ & $10.44 \pm 3.01$ & $9.9 \pm 3.00$ & - & $5.34 \pm 3.02$ & - \\
\hline 18.234 & phella0rene & $0.04 \pm 0.02$ & $0.02 \pm 0.01$ & $0.18 \pm 0.07$ & $0.11 \pm 0.07$ & $0.11 \pm 0.09$ & $0.28 \pm 0.04$ \\
\hline 18.552 & (+)-Limonene & $1.7 \pm 0.14$ & $2.27 \pm 1.34$ & $1.38 \pm 0.22$ & $1.92 \pm 0.14$ & $2.66 \pm 0.53$ & $1.34 \pm 1.07$ \\
\hline 18.56 & $\gamma$-terpinolene & $0.04 \pm 0.03$ & $0.06 \pm 0.03$ & - & $0.16 \pm 0.09$ & $0.14 \pm 0.04$ & $0.16 \pm 0.07$ \\
\hline 23.355 & ocimene & $0.05 \pm 0.04$ & $0.01 \pm 0.01$ & - & $0.09 \pm 0.03$ & - & - \\
\hline 25.475 & (-)- $\alpha$-Ilanoleene & $0.08 \pm 0.03$ & $0.01 \pm 0.01$ & $0.14 \pm 0.10$ & $0.11 \pm 0.01$ & - & - \\
\hline 25.54 & $\alpha$-copaene & $1.83 \pm 0.77$ & $2.49 \pm 1.08$ & $2.89 \pm 0.97$ & $1.96 \pm 0.97$ & $0.38 \pm 0.55$ & $2.05 \pm 1.12$ \\
\hline 25.705 & $\begin{array}{l}\text { beta-elemene } \\
\text { 6-methyl-2-(4-me }\end{array}$ & $0.64 \pm 0.11$ & $0.05 \pm 0.05$ & $0.56 \pm 0.01$ & $0.36 \pm 0.11$ & - & $0.14 \pm 0.08$ \\
\hline 26.249 & $\begin{array}{l}\text { thylcyclohex-3-en } \\
\text { yl)hept-2,5-diene }\end{array}$ & - & $0.29 \pm 0.08$ & - & - & - & $0.12 \pm 0.05$ \\
\hline 26.252 & $\beta$-caryophyllene & $0.3 \pm 0.08$ & $0.31 \pm 0.11$ & $0.32 \pm 0.02$ & $0.26 \pm 0.03$ & - & - \\
\hline 26.846 & $\begin{array}{l}\text { Alpha- } \\
\text { curcumene }\end{array}$ & $3.8 \pm 1.32$ & $3.35 \pm 1.56$ & $3.75 \pm 0.14$ & $2.11 \pm 1.05$ & $0.18 \pm 0.06$ & $1.64 \pm 0.15$ \\
\hline
\end{tabular}




\begin{tabular}{|c|c|c|c|c|c|c|c|}
\hline 26.912 & valencene & $6.04 \pm 3.02$ & $5.37 \pm 2.09$ & $5.13 \pm 3.01$ & $3.42 \pm 0.95$ & - & $1.36 \pm 0.94$ \\
\hline 26.998 & zingiberene & $1.18 \pm 0.18$ & $1.1 \pm 0.19$ & $1.04 \pm 0.24$ & $0.5 \pm 0.17$ & - & $0.27 \pm 0.10$ \\
\hline 27.042 & $\alpha$-farnesene & $0.22 \pm 0.16$ & - & - & $0.11 \pm 0.07$ & - & 0 \\
\hline 27.259 & $\beta$-selinene & $1.33 \pm 0.97$ & $0.9 \pm 0.14$ & $1.11 \pm 0.17$ & $0.67 \pm 0.01$ & - & $0.24 \pm 0.04$ \\
\hline 27.305 & $\begin{array}{c}\text { cis-Ilanoil-4(14),5 } \\
\text {-diene }\end{array}$ & $0.33 \pm 0.04$ & $0.42 \pm 0.18$ & $0.25 \pm 0.04$ & $0.2 \pm 0.13$ & - & 0 \\
\hline 27.407 & $\begin{array}{c}\beta \text {-sesquiphella0re } \\
\text { ne }\end{array}$ & $0.96 \pm 0.16$ & $0.75 \pm 0.21$ & $0.84 \pm 0.14$ & $0.43 \pm 0.16$ & - & $0.21 \pm 0.07$ \\
\hline 27.477 & $(+)$-d-butylene & $0.41 \pm 0.08$ & $0.33 \pm 0.10$ & $0.36 \pm 0.09$ & 0 & - & $0.12 \pm 0.09$ \\
\hline 27.525 & $\begin{array}{c}(-) \text {-cis-calamenen } \\
\mathrm{e}\end{array}$ & $0.31 \pm 0.10$ & $0.03 \pm 0.03$ & $0.29 \pm 0.12$ & $0.21 \pm 0.07$ & - & $0.12 \pm 0.14$ \\
\hline 27.567 & $\alpha$-panasinsene & $1.23 \pm 0.13$ & $0.75 \pm 0.04$ & $0.91 \pm 0.25$ & $0.53 \pm 0.08$ & - & $0.16 \pm 0.07$ \\
\hline 27.652 & $\begin{array}{c}\text { (-)-Alpha-cubebe } \\
\text { ne }\end{array}$ & $0.04 \pm 0.03$ & $0.07 \pm 0.04$ & - & - & - & - \\
\hline 27.813 & $\alpha$-calacorene & $0.08 \pm 0.03$ & $0.05 \pm 0.04$ & $0.06 \pm 0.04$ & $0.06 \pm 0.04$ & - & - \\
\hline 28.001 & 1-Tricene & - & $0.09 \pm 0.05$ & - & - & - & - \\
\hline 29.356 & $\gamma$-selinene & - & $0.27 \pm 0.09$ & $0.35 \pm 0.01$ & $0.24 \pm 0.13$ & - & $0.04 \pm 0.04$ \\
\hline \multirow[t]{2}{*}{22.514} & 4-Allylanisole & $1.49 \pm 0.14$ & $2.51 \pm 1.27$ & $1.21 \pm 0.14$ & $3.36 \pm 1.04$ & $3.63 \pm 1.03$ & $3.02 \pm 0.96$ \\
\hline & Subtotals $(\%)$ & $29.12 \pm 3.38 \mathrm{~A}$ & $31.93 \pm 3.79 \mathrm{~A}$ & $30.68 \pm 4.90 \mathrm{~A}$ & $16.78 \pm 2.21 \mathrm{~A}$ & $12.43 \pm 1.32 B$ & $11.27 \pm 1.17 \mathrm{~B}$ \\
\hline
\end{tabular}

The contents of the volatile compounds were expressed as mean \pm standard deviation $(n=3)$. RI, retention index; Hyphens in content columns mean not detected. Different letters $(\mathrm{A}-\mathrm{C})$ in the same row indicate significant differences among the three groups in the same days. $(p<0.05)$.

Esters with a lower threshold are formed by the esterification reaction of acids and alcohols. The esters formed by short-chain acids have a fruity flavour, while long-chain acids have a greasy taste, which helps produce the special flavour of fermented sausages. Thirty-nine types of esters were detected, including ethyl caproate with an aroma of koji and pineapple, hexyl hexanoate with a fragrant fruit flavour, butyl caprylate with a buttery smell, linalyl formate with an aroma of fruit and rose, and hexyl tiglate which is a synthetic fragrance. As shown in Figure 10, the relative percentage of esters increased with the extension of fermentation time, so flavours gradually accumulated. It also can be found that the relative percentage of esters of $\mathrm{P} 3$ and $\mathrm{P} 3-\mathrm{M} 2$ groups were higher than the control group $(p<0.05)$ after 22 days. In particular, Ethyl 3-methylbutyrate increased by $566 \%$ and $329 \%$, acid ethyl ester by $39.82 \%$, ethyl hexanoate by $65.42 \%$ and $59.81 \%$, linalyl formate by $16.19 \%$ and $51.43 \%$. This can be explained by the fact that strains P3-M2 and P3 helped in the generation of flavour $(p<0.05)$. However, there was no significant difference between P3 and P3-M2 groups ( $p \geq 0.05)$.

A total of 10 types of acids were detected, mainly acetic and hexanoic acids. Acids can directly affect the flavour of sausage and form esters with alcohols. The acid content was high in the initial sausage fermentation process and decreased with the generation and reduction of alcohols. Acids are the main components of fermented sausage flavour substances [5], such as N-hexanoic acid with a flavour similar to dry cheese, are the main components of fermented sausage flavour [5]. On the day 22, acetic acid in P3-M2 groups were significantly lower than those in the control $\operatorname{group}(p<0.05)$.The alcohols and organic acids from the metabolism of lactic acid bacteria could generate the corresponding esterin under the action of esterase (ES) and alkyltransferase (AAT). 
Alcohols are mainly produced by the metabolism of carbohydrates under the action of microorganisms, and some alcohols can also be produced by lipid oxidation. A total of 17 types of alcohols were detected in the three sausage groups, mainly ethanol with a special aroma and slight irritation. The 1-octene-3-alcohol was a strong mushroom-like sweet herb and dry grass-like soil fragrance, 2, 3-butanediol showed a gentle rise and honey-like aroma. From Figure 11, it can be observed that the relative percentage of alcohols showed a trend of rising first and then falling. The increase in the early stage was mainly due to the metabolism of sugars to produce alcohols with the action of microorganisms, while in the later stage, these alcohols could undergo an esterification reaction with acids to form esters, resulting in a decrease in their relative percentage. After the day 22, the alcohols in P3-M2 groups were significantly lower than those in the control group and P3 group $(p<0.05)$.

Aldehydes, which are key components of volatile substances in fermented meat products with a low threshold and a strong odour, are mainly derived from the oxidation of lipids and degradation of amino acids. Nonanal and octanal are produced when unsaturated fatty acids are oxidised. Fourteen types of aldehyde were detected. Benzaldehyde and phenylacetaldehyde, which are produced by the degradation of phenylalanine by Strecker, are related to protein oxidation [40], similar to fruity aromas. Roldan et al. [41] also found that the content of hexanal in cooked mutton was significantly related to TBARs, possibly due to the free radicals produced by the rapid oxidation of lipids. In our study, the relative percentages of benzaldehyde and phenylacetaldehyde showed an upward trend. Moreover, the relative percentages of benzaldehyde and phenylacetaldehyde in the P3 and P3-M2 groups was lower than that in the control group, confirming that the carbonyl group was gradually formed during fermentation, and L. plantarum P3 could slow down the generation of carbonyl groups ( $p$ $<0.05)$.

Most of the ketones have a milky or fruity flavour, with a lower threshold, which is an important component of the special flavour of sausages. For example, the relatively high content of 3-hydroxy-2-butanone, which has a buttery taste, plays an important role in the special flavour of fermented sausages. The ketone content in the three sausage groups was less and with no significant difference $(p \geq 0.05)$.

Alkenyl terpenoids are mainly derived from these species. From Figure 10, it was found that the total relative percentage of alkenyl terpenoids in the P3 and P3-M2 groups was higher than that in the control group $(p<0.05)$. This may be because the addition of lactic acid bacteria changes the environment of fermentation and promotes the volatilization of flavour in spices.

Based on these results, it can be considered that L. plantarum strains with antioxidant ability may affect flavour through protein and lipid oxidation pathways. In the process of amino acid metabolism of LAB, amino acids mainly pass through four metabolic pathways to produce volatile aroma components (Figure 11(a)). One of the amino acid pathways was associated with two kinds of dehydrogenase, $\alpha$-ketate dehydrogenase and hydroxy acid dehydrogenase. Through these ways, the LAB strains with antioxidant ability may enhance the degradation of amino acid, and promote the aldehyde to produce more alcohols through reduction reaction. Thus from this way, more esters were formed by the reaction of alcohol and acid with the esterase.

Additionally free fatty acids would be produced under the action of esterase, and fatty acids can be further oxidised to produce flavour substances, such as short-chain fatty acids and aliphatic aldehydes(Figure 11(b)). Then the saturated, unsaturated fatty acids and some of the fatty acids were oxidised or $\beta$-oxidated to inform alcohol and acid. In our study, it was confirmed that strains P3 and P3-M2 can reduce the oxidation of free fatty acid by inhibiting LOX activity. By the lipid pathway, alcohol and acid were decreased while the ester was increased. 


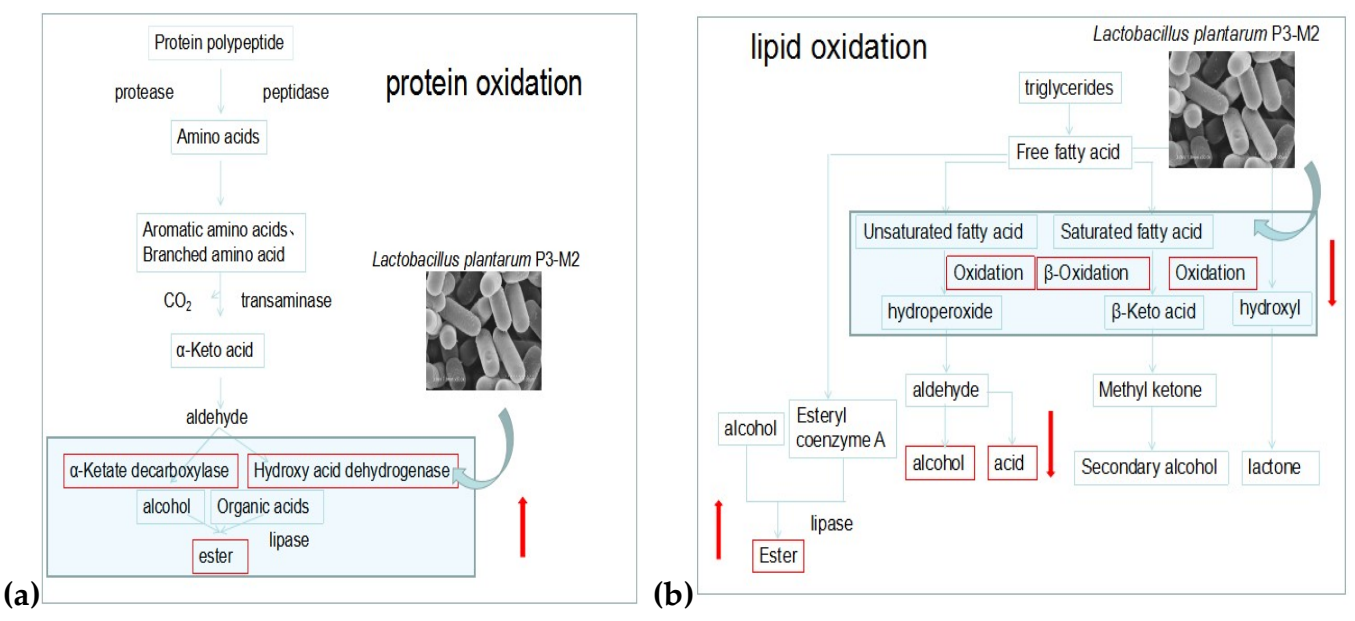

Figure 11. Primarily metabolic pathways of protein (a) and lipid (b) associated with flavour formation in LAB

\section{Conclusions}

Our results indicated that L. plantarum strains P3-M2 and P3 with high antioxidant properties enhance the flavour of Chinese sausages through the reduction of lipid and protein oxidation. The retardation of the oxidation of lipids and proteins in Chinese sausages during storage may be attributed to the antioxidant ability of L. plantarum, which changes the alleviation of flavour substances, such as inducing ester and reducing some kinds of alcohol and acid. This study provides valuable information to enhance the flavour of Chinese fermented sausages with the antioxidant L. plantarum strain. However, further studies are needed to support new evidence regarding the other mechanisms of the sausage flavour of L. plantarum with anti-oxidization ability.

Author Contributions: Conceptualization, L.M. and L.W.; methodology, L.M and D.M.P.; formal analysis, D.M.P and T.T.G.; writing-original draft preparation, D.M.P.; writing-review and editing, L.M and Y.L.Wang; data curation, D.M.P. and Q.Y.J.. All authors have read and agreed to the published version of the manuscript.

Conflicts of Interest: The authors declare no conflict of interest.

\section{References}

1. Xiao, Y.; Liu, Y.; Chen, C.; Xie, T.; Li, P. Effect of Lactobacillus plantarum and Staphylococcus xylosus on flavour development and bacterial communities in Chinese dry fermented sausages. Food Research International 2020, 135, 109247, doi:https://doi.org/10.1016/j.foodres.2020.109247.

2. Bartkiene, E.; Bartkevics, V.; Mozuriene, E.; Lele, V.; Zadeike, D.; Juodeikiene, G. The Safety, Technological, Nutritional, and Sensory Challenges Associated With Lacto-Fermentation of Meat and Meat Products by Using Pure Lactic Acid Bacteria Strains and Plant-Lactic Acid Bacteria Bioproducts. Front. Microbiol. 2019, 10, 4, doi:10.3389/fmicb.2019.01036.

3. Bancalari, E.; Montanari, C.; Levante, A.; Alinovi, M.; Neviani, E.; Gardini, F.; Gatti, M. Lactobacillus paracasei 4341 as adjunct culture to enhance flavor in short ripened Caciotta-type cheese. Food Research International 2020, 135, 109284, doi:https://doi.org/10.1016/j.foodres.2020.109284.

4. Zheng, Y.; Fei, Y.; Yang, Y.; Jin, Z.; Yu, B.; Li, L. A potential flavor culture: Lactobacillus harbinensis M1 improves the organoleptic quality of fermented soymilk by high production of 2,3-butanedione and acetoin. Food Microbiology 2020, 91, 103540, doi:https://doi.org/10.1016/j.fm.2020.103540. 
5. Hu, Y.; Zhang, L.; Liu, Q.; Wang, Y.; Chen, Q.; Kong, B. The potential correlation between bacterial diversity and the characteristic volatile flavour of traditional dry sausages from Northeast China. Food Microbiology 2020, 91, 103505, doi:https://doi.org/10.1016/j.fm.2020.103505.

6. Li, R.-Y.; Zheng, X.-W.; Zhang, X.; Yan, Z.; Wang, X.-Y.; Han, B.-Z. Characterization of bacteria and yeasts isolated from traditional fermentation starter (Fen-Daqu) through a 1H NMR-based metabolomics approach. Food Microbiology 2018, 76, 11-20, doi:https://doi.org/10.1016/j.fm.2018.03.015.

7. Feng, X.; Tjia, J.Y.Y.; Zhou, Y.; Liu, Q.; Fu, C.; Yang, H. Effects of tocopherol nanoemulsion addition on fish sausage properties and fatty acid oxidation. LWT 2020, 118, 108737, doi:https://doi.org/10.1016/j.lwt.2019.108737.

8. Cheng, J.; Xiang, R.; Tang, D.; Zhu, M.; Liu, X. Regulation of protein oxidation in Cantonese sausages by rutin, quercetin and caffeic acid. Meat Science 2021, 175, 108422, doi:https://doi.org/10.1016/j.meatsci.2020.108422.

9. Jiang, Y.; Li, D.; Tu, J.; Zhong, Y.; Zhang, D.; Wang, Z.; Tao, X. Mechanisms of change in gel water-holding capacity of myofibrillar proteins affected by lipid oxidation: The role of protein unfolding and cross-linking. Food Chemistry 2021, 344, 128587, doi:https://doi.org/10.1016/j.foodchem.2020.128587.

10. Domínguez, R.; Pateiro, M.; Gagaoua, M.; Barba, F.J.; Zhang, W.; Lorenzo, J.M. A Comprehensive Review on Lipid Oxidation in Meat and Meat Products. Antioxidants 2019, 8.

11. Papuc, C.; Goran, G.V.; Predescu, C.N.; Nicorescu, V. Mechanisms of Oxidative Processes in Meat and Toxicity Induced by Postprandial Degradation Products: A Review. Compr. Rev. Food. Sci. Food Saf. 2017, 16, 96-123, doi:10.1111/1541-4337.12241.

12. Smaoui, S.; Hsouna, A.B.; Lahmar, A.; Ennouri, K.; Mtibaa-Chakchouk, A.; Sellem, I.; Najah, S.; Bouaziz, M.; Mellouli, L. Bio-preservative effect of the essential oil of the endemic Mentha piperita used alone and in combination with BacTN635 in stored minced beef meat. Meat Science 2016, 117, 196-204, doi:https://doi.org/10.1016/j.meatsci.2016.03.006.

13. Zhang, D.; Li, H.; Wang, Z.; Emara, A.M.; Hu, Y.; He, Z. Effects of in vitro oxidation on myofibrillar protein charge, aggregation, and structural characteristics. Food Chemistry 2020, 332, 127396,

doi:https://doi.org/10.1016/j.foodchem.2020.127396.

14. Ge, Q.; Chen, S.; Liu, R.; Chen, L.; Yang, B.; Yu, H.; Wu, M.; Zhang, W.; Zhou, G. Effects of Lactobacillus plantarum NJAU-01 on the protein oxidation of fermented sausage. Food Chemistry 2019, 295, 361-367,

doi:https://doi.org/10.1016/j.foodchem.2019.05.154.

15. Noureen, S.; Riaz, A.; Arshad, M.; Arshad, N. In vitro selection and in vivo confirmation of the antioxidant ability of Lactobacillus brevis MG000874. J. Appl. Microbiol. 2019, 126, 1221-1232, doi:10.1111/jam.14189.

16. Van Ba, H.; Seo, H.-W.; Cho, S.-H.; Kim, Y.-S.; Kim, J.-H.; Ham, J.-S.; Park, B.Y.; Pil Nam, S. Antioxidant and anti-foodborne bacteria activities of shiitake by-product extract in fermented sausages. Food Control 2016, 70, 201-209, doi:https://doi.org/10.1016/j.foodcont.2016.05.053.

17. Lin, M.Y.; Yen, C.L. Inhibition of lipid peroxidation by Lactobacillus acidophilus and Bifidobacterium longum. J Agric Food Chem 1999, 47, 3661-3664.

18. Liang, X.L.; Wang, X.L.; Li, Z.; Hao, Q.H.; Wang, S.Y. Improved in Vitro Assays of Superoxide Anion and 1,1-Diphenyl-2-picrylhydrazyl (DPPH) Radical-Scavenging Activity of Isoflavones and Isoflavone Metabolites. J. Agric. Food Chem. 2010, 58, 11548-11552, doi:10.1021/jf102372t.

19. Lim, H.J.; Kim, G.D.; Jung, E.Y.; Seo, H.W.; Joo, S.T.; Jin, S.K.; Yang, H.S. Effect of Curing Time on the Physicochemical and Sensory Properties of Beef Jerky Replaced Salt with Soy Sauce, Red Pepper Paste and Soybean Paste. Asian Australas. J. Anim. Sci. 2014, 27, 1174-1180, doi:10.5713/ajas.2013.13853.

20. Witte, V.C.; Krause, G.F.; Bailey, M.E. A new extraction method for determining 2-thiobarbituric acid values for pork and beef during storage. Journal of Food Science 1970, 35, 585-592. 
21. Liu, Y.; Li, J.W.; Cheng, Y.J.; Liu, Y.F. Effect of frying oils' fatty acid profile on quality, free radical and volatiles over deep-frying process: A comparative study using chemometrics. LWT-Food Sci. Technol. 2019, 101, 331-341, doi:10.1016/j.lwt.2018.11.033.

22. Yu, D.; Feng, M.-q.; Sun, J.; Xu, X.-1.; Zhou, G.-h. Protein degradation and peptide formation with antioxidant activity in pork protein extracts inoculated with Lactobacillus plantarum and Staphylococcus simulans. Meat Science 2020, 160, 107958, doi:https://doi.org/10.1016/j.meatsci.2019.107958.

23. Soglia, F.; Petracci, M.; Ertbjerg, P. Novel DNPH-based method for determination of protein carbonylation in muscle and meat. Food Chemistry 2016, 197, 670-675, doi:https://doi.org/10.1016/j.foodchem.2015.11.038.

24. Wang, Z.; He, Z.; Gan, X.; Li, H. Effect of peroxyl radicals on the structure and gel properties of isolated rabbit meat myofibrillar proteins. International Journal of Food Science and Technology 2018, 53, 2687-2696, doi:10.1111/ijfs.13878.

25. Smaoui, S.; Ennouri, K.; Chakchouk-Mtibaa, A.; Karray-Rebai, I.; Hmidi, M.; Bouchaala, K.; Mellouli, L. Relationships Between Textural Modifications, Lipid and Protein Oxidation and Sensory Attributes of Refrigerated Turkey Meat Sausage Treated with Bacteriocin BacTN635. Food and Bioprocess Technology 2017, 10, 1655-1667, doi:10.1007/s11947-017-1933-0.

26. Chen, Q.; Kong, B.; Han, Q.; Liu, Q.; Xu, L. The role of bacterial fermentation in the hydrolysis and oxidation of sarcoplasmic and myofibrillar proteins in Harbin dry sausages. Meat Science 2016, 121, 196-206, doi:https://doi.org/10.1016/j.meatsci.2016.06.012.

27. Song, Y.; Qiao, N.; Li, C.W.; Wen, T.T.; Liu, F.Y. SPME-GC/MS Analysis of Volatile Components from Air-dried Sausage during Processing. Advanced Materials Research 2013, 781-784, 1614-1618.

28. Latoch, A.; Libera, J. Quality and Safety of Pork Steak Marinated in Fermented Dairy Products and Sous-Vide Cooked. Sustainability 2019, 11, doi:10.3390/su11205644.

29. Das, D.; Goyarl, A. Antioxidant activity and gamma-aminobutyric acid (GABA) producing ability of probiotic Lactobacillus plantarum DM5 isolated from Marcha of Sikkim. LWT-Food Sci. Technol. 2015, 61, 263-268, doi:10.1016/j.lwt.2014.11.013.

30. Bian, H.; Ma, J.; Geng, Z.; Liu, T.; Sun, C.; Wang, D.; Zhang, M.; Xu, W. Changes of hydroxyl-linoleic acids during Chinese-style sausage processing and their relationships with lipids oxidation. Food Chemistry 2019, 296, 63-68, doi:https://doi.org/10.1016/j.foodchem.2019.05.183.

31. Li, B.; Xu, Y.; Li, J.; Niu, S.; Wang, C.; Zhang, N.; Yang, M.; Zhou, K.; Chen, S.; He, L., et al. Effect of oxidized lipids stored under different temperatures on muscle protein oxidation in Sichuan-style sausages during ripening. Meat Science 2019, 147, 144-154, doi:https://doi.org/10.1016/j.meatsci.2018.09.008.

32. Sharedeh, D.; Gatellier, P.; Astruc, T.; Daudin, J.-D. Effects of pH and $\mathrm{NaCl}$ levels in a beef marinade on physicochemical states of lipids and proteins and on tissue microstructure. Meat Science 2015, 110, 24-31,

doi:https://doi.org/10.1016/j.meatsci.2015.07.004.

33. Korzeniowska, M.; Kroliczewska, B.; Kopec, W. Carbonyl and sulfhydryl groups of chicken meat proteins after dietary modulation with selenium. Open Chemistry 2015, 13, 1293-1302, doi:10.1515/chem-2015-0147.

34. Zhang, L.; Lin, Y.H.; Leng, X.J.; Huang, M.; Zhou, G.H. Effect of sage (Salvia officinalis) on the oxidative stability of Chinese-style sausage during refrigerated storage. Meat Science 2013, 95, 145-150,

doi:https://doi.org/10.1016/j.meatsci.2013.05.005.

35. Cheng, J.; Xu, L.; Xiang, R.; Liu, X.; Zhu, M. Effects of mulberry polyphenols on oxidation stability of sarcoplasmic and myofibrillar proteins in dried minced pork slices during processing and storage. Meat Science 2020, 160, 107973, doi:https://doi.org/10.1016/j.meatsci.2019.107973.

36. Zhao, C.J.; Schieber, A.; Gänzle, M.G. Formation of taste-active amino acids, amino acid derivatives and peptides in food fermentations - A review. Food Research International 2016, 89, 39-47, doi:https://doi.org/10.1016/j.foodres.2016.08.042. 
37. Sun, W.; Zhao, H.; Zhao, Q.; Zhao, M.; Yang, B.; Wu, N.; Qian, Y. Structural characteristics of peptides extracted from Cantonese sausage during drying and their antioxidant activities. Innov. Food Sci. Emerg. Technol. 2009, 10, 558-563, doi:https://doi.org/10.1016/j.ifset.2009.07.006.

38. Sante-Lhoutellier, V.; Aubry, L.; Gatellier, P. Effect of oxidation on in vitro digestibility of skeletal muscle myofibrillar proteins. J. Agric. Food Chem. 2007, 55, 5343-5348, doi:10.1021/jf070252k.

39. Smid, E.J.; Kleerebezem, M. Production of Aroma Compounds in Lactic Fermentations. In Annual Review of Food Science and Technology, Vol 5, Doyle, M.P., Klaenhammer, T.R., Eds. Annual Reviews: Palo Alto, 2014; Vol. 5, pp. 313-326.

40. Delgado, F.J.; González-Crespo, J.; Cava, R.; Ramírez, R. Changes in the volatile profile of a raw goat milk cheese treated by hydrostatic high pressure at different stages of maturation. International Dairy Journal 2011, 21, 135-141, doi:https://doi.org/10.1016/j.idairyj.2010.10.006.

41. Roldan, M.; Antequera, T.; Armenteros, M.; Ruiz, J. Effect of different temperature-time combinations on lipid and protein oxidation of sous-vide cooked lamb loins. Food Chemistry 2014, 149, 129-136, doi:10.1016/j.foodchem.2013.10.079. 